\title{
Ülke Risk Primi Şokunun Bankacılık Sisteminin Sağlamlığına Etkisi: SVAR Modeli Çerçevesinde Türkiye Örneği
}

\author{
Serdar VARLIK, Department of Economics, Hitit University, Turkey; e-mail: serdarvarlik@ hitit.edu.tr
}

\section{The Effect of Sovereign Risk Premium Shock on Banking System Soundness: The Case of Turkey in the Framework of SVAR Model}

\begin{abstract}
In this study covering the period of January 2004-June 2015 for Turkish economy, using structural vector autoregression (SVAR) model, the effects of sovereign risk premium shocks on banking system soundness are investigated. According to the results of impulse response analyses, against to one standard deviation structural shock in sovereign risk premium; (i) Turkish Lira (TL) depreciates, financial stock prices declines, interbank overnight interest rate goes up, banking system soundness index $(B S I)$ declines and eventually credit-deposit interest rate spread increases. However, (ii) credit-deposit interest rate spread responses to sovereign risk premium shock longer time than other variables do. This evidence exhibits that the balance sheet structure of banking sector is strong against to sovereign risk premium shock and banking sector reflects the negative effects of shock to real economy via increasing credit-deposit interest rate spread. The results of impulse response analysis are supported by the evidences of variance decomposition.
\end{abstract}

Keywords $\quad$ : Banking Sector Soundness Index, Sovereign Risk Premium, SVAR.

JEL Classification Codes : $\quad$ E40, E44, E50.

\section{Öz}

Türkiye ekonomisi için Ocak 2004-Haziran 2015 dönemini kapsayan bu çalışmada, yapısal vektör otoregresyon (SVAR) modeli kullanılarak, ülke risk primi şoklarının bankacılık sisteminin sağlamlığı üzerindeki etkileri incelenmektir. Etki-tepki analizinin sonuçlarına göre ülke risk primindeki bir standart sapma yapısal şok karşısında (i) Türk Lirası (TL) değer kaybetmekte, finansal hisse senedi fiyatları düşmekte, bankalar arası para piyasası gecelik faiz oranı yükselmekte, bankacılık sağlamlık endeksi $(B S I)$ düşmekte ve sonuçta kredi mevduat faiz farkı yükselmektedir. Ancak, (ii) kredi-mevduat faiz farkı ülke risk primi şokuna diğer değişkenlerden daha uzun süre tepki vermektedir. Bu bulgu bankacılık sektörünün bilânço yapısının ülke risk primi şoku karşısında güçlü olduğunu ve bankacılık sektörünün şokun olumsuz etkilerini artan kredi-mevduat faiz farkı aracılığıyla reel ekonomiye yansıttığını ortaya koymaktadır. Etki-tepki analizinin sonuçları varyans ayrıştırması bulguları tarafindan desteklemektedir.

Anahtar Sözcükler $\quad$ : Bankacılık Sağlamlık Endeksi, Ülke Risk Primi, SVAR. 
Varlık, S. (2017), “Ülke Risk Primi Şokunun Bankacılık Sisteminin Sağlamlığına Etkisi:

SVAR Modeli Çerçevesinde Türkiye Örneği”, Sosyoekonomi, Vol. 25(33), 103-126.

\section{Giriș}

Ülke risk primi şokları Türkiye gibi Yükselen Piyasa Ekonomileri'nde (YPE) finansal istikrarı ve para politikasının başarısını olumsuz yönde etkilemektedir. YPE'lerde ülke risk primi ölçütü için yaygın olarak kullanılan değişkenlerin başında, JP Morgan Chase tarafından geliştirilen EMBI+ (Emerging Market Bond Index) gelmektedir ${ }^{1}$. EMBI+, YPE'lerde mali baskınlık probleminin varlı̆̆ hakkında bilgi vermektedir (Blanchard, 2004). Bununla birlikte EMBI+, YPE'lerin finansal piyasalarında meydana gelen dalgalanmaları (Neumeyer \& Perri, 2005; Garcia-Herero \& Ortiz, 2006; Carare \& Popescu, 2011) ve bu ülkelerin sermaye akımlarına bağlı dışsal şoklar karşısındaki kırılganlıklarını yansıtması açısından da önem taşımaktadır (Calvo, 2002; González-Rozada \& Levy-Yeyati, 2008). Ülke risk primi artışları sonucunda ulusal para biriminin değeri aşınırken başta bankacılık sektörü olmak üzere YPE'lerin finansal piyasaları olumsuz yönde etkilenmektedir (Gertler vd., 2007; Davies \& Ng, 2011; Castro \& Mencia, 2014).

Farklı ülkeler için yapılan ampirik çalışmalar EMBI+'daki artışların farklı nedenlerden tetiklenerek geliştiğini göstermektedir. Nogués and Grandes (2001), Blanchard (2004), Favero ve Giavazzi (2004) ve Nickel vd. (2009) ülke risk primindeki artışları mali disiplinin sağlanamaması ve YPE'lerin dış borç yapılarının sürdürülemez olmasıyla açıklarken, Baldacci vd. (2008), Bellas vd. (2010), Martinez vd. (2013) ve Kennedy ve Palern (2014) ise zayıf makroekonomik temellerle ve YPE'lerde yaşanan politik istikrarsızlıklarla açıklamaktadırlar. Ancak, enflasyon hedeflemesine geçmeden önce mali baskınlık problemini önlemek için gerçekleştirilen yasal düzenlemeler ve maliye politikalarının enflasyon hedefleriyle uyumlu olacak şekilde uygulanması, YPE'lerin ülke risk primindeki artışların yurt içi nedenlerinin görece hafiflemesini sağlamıştır (Agénor \& Pereria da Silva, 2013). YPE'lerde enflasyon hedeflemesine geçildikten sonra ülke risk priminin azalması, bu durumu destekleyen bir gelişmedir (Fouejieu \& Roger, 2013). Bu noktada, ülke risk primindeki artışların dışsal koşullardaki değişimle açıklanabilmesi, sermaye akımlarının durması (sudden stop) ya da tersine dönmesi (capital outflow) olarak tanımlanan dışsal baskınlık ${ }^{2}$ (external dominance) problemiyle yakından ilişkili olduğunu göstermektedir (Fraga vd., 2003). Ferrucci (2003), Fracasso (2007), González-Rozada ve Levy-Yeyati (2008), Levy-Yeyati ve Williams (2010), Cheikh ve Amadou (2013), Özmen ve Yaşar (2015) ülke risk primindeki artışların küresel likidite koşullarındaki ve risk iştahındaki değişimlerden, sermaye akımlarındaki ve uluslararası faiz oranlarındaki

1 Ülke risk priminin bir diğer ölçütü, kredi temerrü̈t takası oranıdır (Credit Default Swap; CDS). Ülkelerin temerrüde düşme riskinin ölçütü olarak kullanılan CDS oranı, borçlanan tarafin (ülkenin) temerrüde düşmesi durumunda, borç verenlerin olası zararlarını karşılayabilmeleri için CDS satıcılarına yükümlülüklerinin belirli bir oranı kadar ödedikleri yıllık primlerdir.

2 Dışsal baskınlık problemi, YPE'lere yönelik sermaye girişlerinin aniden durması ve/veya tersine dönmesi sonucunda döviz kurunda ve ülke risk priminde meydana gelen şokların para politikasının başarısını olumsuz yönde etkilemesi durumudur. Dışsal baskanlık problemi, enflasyon beklentilerinin yönetimini zorlaştırmakta ve para politikasının güvenilirliğini azaltarak merkez bankalarının enflasyonu kontrol etmekteki başarısını olumsuz yönde etkilemektedir (Fraga vd., 2003). 
dalgalanmalardan ve bölgesel şokların bulaşıcılığından kaynaklandığını belirtmektedirler. Beck (2001), Çulha vd. (2006) ve Özatay vd. (2009) ise makroekonomik temellerin zayıf olduğu YPE'lerde, küresel likidite koşullarının, uluslararası faiz oranlarına ilişkin gelişmelerin ve yükselen risk algısının ülke risk primindeki artışları tetiklediğini ifade etmektedirler.

Mali baskınlık problemini önlemek için yapılan yasal düzenlemeler ve mali disiplin çerçevesinde uygulanan maliye politikaları sayesinde Türkiye ekonomisinde açık enflasyon hedeflemesine geçmeden önce mali baskınlık problemi belirgin bir biçimde azaltılmıştır (TCMB, 2005a; Kara, 2006; Başçı vd., 2007; Ersel \& Özatay, 2008). Bu eğilimin açık enflasyon hedeflemesine geçildikten sonra da devam etmesi, mali baskınlık problemi nedeniyle ülke risk priminde ortaya çıkabilecek artışların yaşanması olasılığını azaltmaktadır. Buna karşın, sermaye akımlarında yaşanan dalgalanmalara bağlı olarak Türkiye'nin ülke risk priminin belirli dönemlerde yükselme eğiliminde olması (Özatay, 2014), finansal istikrarı ve para politikasının başarısını olumsuz yönde etkilemektedir (BDDK, 2010; TCMB, 2014; OECD, 2014; Başç1, 2015).

İktisat yazınında farklı ülkelere ait EMBI+ endeksleri ile bu ülkelerin makro ekonomik ve finansal değişkenleri arasındaki ilişkileri inceleyen çok sayıda ampirik çalışma bulunmaktadır. 2008 Küresel Krizi'nin ardından bu çalışmaların giderek yaygınlaştığ 1 görülmektedir. Bunlara örnek olarak Goldfajn ve Olivares (2001), Gertler vd. (2007), Allegret ve Sand (2009), Mandelman (2010), Galindo vd. (2010), Carare ve Popescu (2011), Swiston (2011), Majnoni ve Powell (2011), Castro ve Mencia (2014), Kılınç ve Tunç (2014) ve Portillo ve Ustyugova (2015) verilebilir. Daha önce yapılmış olan çalışmalardan farklı olarak bu çalışmanın katkısı; Türkiye için ülke risk priminin bir ölçütü olarak kullanılan $E M B I+T R$ 'de meydana gelen şokların bankacılık sektörünün bilânçosuna ve aracılık faaliyetlerine olan etkilerini incelemektedir. Bu kapsamda bankacılık sektörünün bilânço yapısının sağlamlığını bütüncül olarak değerlendirmek amacıyla Bankacılık Sağlamlık Endeksi (BSI) oluşturulmaktadır. Çalışmada oluşturulan BSI'nın, diğer ulusal ve uluslararası kurumların oluşturduğu endekslerden farklı olan yanı; sermaye yeterliliği ve aktif kalitesi, kârlılık, piyasa riski gibi bileşenlere ek olarak kredi riski bileşenine yer vermesidir. BSI'nın ülke risk primi şokuna verdiği tepkinin anlamlı bulunması, endeksin açıklayıcı gücünü göstermektedir.

Çalışmanın amacı, Türkiye ekonomisinde Ocak 2004-Haziran 2015 döneminde $E M B I+T R$ 'de meydana gelen şokların bankacılık sektörünün sağlamlığını ve aracılık faaliyetlerini ne şekilde etkilediğini ortaya koymaktır. Çalışmaya konu olan dönem, BSI oluşturulurken kullanılan veri setinin yeterliliği dikkate alınarak tercih edilmiştir. Bu çerçevede çalışmada izlenen yöntem iki aşamadan oluşmaktadır. Birinci aşamada standardize edilen değişkenler ile faktör analizi yapılarak BSI oluşturulmaktadır. İkinci aşamada yapısal vektör otoregresyon (Structural Vector Autoregression; SVAR) yöntemi kullanılarak $E M B I+T R$ şokunun bankacılık sektörünün sağlamlığına ve aracılık faaliyetlerine olan etkisi incelenmektedir. Bunun için iktisat teorisine uygun kısıtlar konularak etki-tepki analizi ve varyans ayrıştırması yöntemi uygulanmaktadır. 
Çalışma giriş ve sonuç bölümleri ile birlikte altı bölümden oluşmaktadır. Girişin ardından ikinci bölümde Türkiye ekonomisi için oluşturulan BSI tanımlanmaktadır. Üçüncü bölümde çalışmada kullanılan veri seti açıklanmakta ve durağanlık testlerine yer verilmektedir. Dördüncü bölümde çalışmanın ampirik yöntemi olan SVAR modeli açıklanmaktadır. Beşinci bölümde, etki-tepki analizlerinden ve varyans ayrıştırmasından elde edilen ampirik bulgular sunulmaktadır. Sonuç bölümünde ise çalışmanın bulguları değerlendirilmektedir.

\section{Türkiye Ekonomisi İçin Bankacılık Sağlamlık Endeksinin (BSI) Oluşturulması}

2000’li yıllardan başlamak üzere, uluslararası kuruluşlar ve birçok ülkenin merkez bankası finansal istikrara yönelik tehditleri daha önce saptamak ve finansal sistemin güçlü ve kırılgan yönlerini değerlendirmek amacıyla finansal sistemdeki gelişmeleri açıklayan endeksler oluşturmaya başlamışlardır. Bu endeksler, hem tüm ülkelerin finansal sistemlerini karşılaştırmaya yardımcı olan hem de ülkelere özgü nitelikleri ortaya çıkaran değişkenlerden oluşmaktadır.

$\mathrm{Bu}$ yönde sürdürülen çabaların başında Uluslararası Para Fonu'nun (IMF) 2000 yılında oluşturduğu ve 2007 yılına kadar kapsamını genişlettiği finansal sağlamlık ölçütleri gelmektedir. IMF'in geliştirdiği finansal sağlamlık ölçütleri, temel ve önerilen göstergeler olmak üzere iki farklı gösterge setinden oluşmaktadır. Bankacılık sistemine ilişkin temel gösterge seti, sermaye yeterliliği, aktif kalitesi, kârlılık, likidite ve piyasa riskine duyarlılık bileşenlerini içermektedir. Önerilen gösterge setinde ise, bankacılık sisteminin yanında banka dışı finansal kurumlar, hanehalkları, piyasa likiditesi ve konut piyasası ile ilgili değişkenler bulunmaktadır (IMF, 2006).

Türkiye ekonomisi için yapılan endeks çalışmaları, finansal sistem ağırlıklı olarak bankalardan oluştuğu için, bankacılık sisteminin bilânço yapısını açıklayan değişkenlerden oluşmaktadır. Bu çalışmaların başında TCMB'nin (2005b) oluşturduğu finansal sağlamlık endeksi gelmektedir. TCMB'nin 2005 yilında oluşturduğu finansal sağlamlık endeksi aktif kalitesi, likidite, kur riski, kârlılık ve sermaye yeterliliği gibi alt bileşenlerden oluşmaktadır. TCMB (2006), 2006 yılından itibaren endeksin alt bileşenlerine faiz riskini eklemiştir. Bununla birlikte 2011 yılında TCMB (2011) tarafından "finansal istikrarın makro gösterimi" için küresel ekonomi, küresel piyasalar, yurtiçi ekonomi, yurtiçi piyasalar, ödemeler dengesi, firmalar, hanehalkları ve bankacılık kesimini kapsayan geniş bir değişken seti geliştirilmiştir. Konu ile ilgili çalışma yapan kurumlardan bir diğeri de Bankacılık Düzenleme ve Denetleme Kurumu'dur (BDDK). BDDK (2004), 2003 y1lından itibaren bankacılık sisteminin performansını değerlendirmek için IMF'nin önerdiği finansal sağlamlık göstergeleri çerçevesinde bankacılık sektörü performans endeksini (BDDK-PE) oluşturmuştur. BDDK-PE'de likidite, sermaye yeterliliği, kur riski, kârlılık ve aktif kalitesi bileşenleri yer almaktadır. TCMB'nin geliştirdiği finansal sağlamlık endeksinden farklı olarak BDDK-PE'de, faiz riski alt bileşeni bulunmamaktadır (BDDK, 2010). 
$\mathrm{Bu}$ noktadan hareketle bankacılık sektörünün bilânço yapısını değerlendirmek amacıyla, çalışmada IMF'nin geliştirdiği finansal sağlamlık göstergeleri, TCMB'nin geliştirdiği finansal sağlamlık endeksi ve BDDK'nın geliştirdiği bankacılık performans endeksi dikkate alınarak faktör analizi yöntemi ile Türkiye ekonomisi için bankacılık sağlamlık endeksi (BSI) oluşturulmaktadır. Oluşturulan endeksin diğer ulusal ve uluslararası kurumların oluşturduğu endekslerden farkı; kredi riskinin bir alt bileşen olarak BSI'ya eklenmiş olmasıdır.

Endekse kredi riskinin eklenmesinin iki nedeni bulunmaktadır: (i) Basel Komitesi (1988) bankaların karşı karşıya kaldıkları risk türlerinden en önemlisinin kredi riski (karşı taraf riski) olduğunu ifade etmektedir. (ii) Kredi hacmindeki genişleme endeksi artırmaktadır. Ancak aynı zamanda, Başçı ve Kara (2011), Özatay (2011), Akkaya ve Gürkaynak (2012) ve Kara (2012)'nın da belirttiği gibi, özellikle kısa vadeli sermaye akımlarının tetiklediği hızlı kredi genişlemeleri hanehalkı borçluluk oranını artırmakta, geri ödeyememe riskini yükseltmekte ve cari açık problemini tetikleyerek finansal sistemin istikrarı açısından tehdit oluşturmaktadır. Dolayısıyla endekste kredi riski bileşeninin kullanılması, kredi hacmindeki genişlemenin yaratacağı bu tür olumsuzlukların etkisinin endekse yansımasını sağlamaktadır.

Çalışmada oluşturulan BSI, Ocak 2004-Haziran 2015 dönemini kapsamaktadır. Endeks oluşturulurken tüm serilerin bir araya getirilecek biçimde standardize edilerek dönüştürülmesi gerekmektedir (Cooper, 1983). Bunun için normalizasyon yöntemi kullanılmıştır. Ardından faktör analizine uygunluk testi yapılmış ve finansal sağlamlığa ilişkin veri setinin faktör analizine uygun olduğu saptanmıştır ${ }^{3}$. Faktör analizi sonucunda sermaye yeterliliği ve aktif kalitesi, kârlılık, kredi riski ve piyasa riski (faiz riski + kur riski) olmak üzere dört temel bileşenin bir araya getirilmesi ile BSI oluşturulmuştur. Endeksin bileşenlerinde yer alan tüm değişkenler Hair vd. (2006)' den hareketle faktör yüklerine göre ağırlıklandırılmıştır. BSI'nın bileşenleri Ek-1'de yer alan Tablo 1'de sunulmaktadır.

Endekste yer alan bileşenler kullanılarak oluşturulan BSI, Ek-1'de yer alan Grafik 1'de gösterilmektedir. BSI'nın pozitif olduğu dönemlerde, sektörün sağlamlık düzeyi ortalamanın üzerinde gerçekleşirken, negatif olduğu dönemlerde sektörün sağlamlık düzeyi ortalamanın altına düşmektedir. BSI'nın yurtiçi ve yurt dışı finansal piyasalarda yaşanan gelişmelerle uyumlu bir eğilim içinde olması, endeksin ilgili dönem için bankacılık sektörünün bilânço yapısını açıklama gücünü ortaya koymaktadır.

3 Barlett Testi yapılarak korelasyon matrisinin birim matris olduğuna dair $H_{0}$ hipotezi reddedilmiştir. Bununla birlikte örneklem yeterliliğini ölçen Kaiser-Meyer-Olkin (KMO) Testi sonucunun 0,656 olması, endeks için kullanılan veri setinin faktör analizine uygun olduğunu göstermektedir. 


\section{Veri Setinin Tanımlanması ve Durağanlık Testleri}

Türkiye ekonomisi için aylık verilerle Ocak 2004-Haziran 2015 dönemini kapsayan bu çalışmada SVAR yöntemi kullanılarak tahmin edilen otoregresif model altı içsel ve üç dışsal değişkenden oluşmaktadır. İçsel değişkenler Türkiye'nin ülke risk primi $(E M B I+T R)$, reel efektif döviz kuru (REER), finansal sektörün hisse senedi fiyat endeksi (BISTFIN), bankalararası para piyasası gecelik faiz oranı (INTON), bankacılık sağlamlık endeksi $(B S I)$ ve kredi-mevduat faiz farkıdır (SPREAD). Dışsal değişkenler ise ABD’nin iki yıllık hazine tahvillerinin faiz oranı $(U S T W O)$, brent petrolün varil fiyatı \$ $(O I L)$ ve küresel risk iştahı $(V I X)$ endeksidir.

Türkiye'nin on yıllık USD cinsinden tanımlı Hazine tahvillerinin faiz oranı ile ABD'nin on yıllık Hazine tahvillerinin faiz oranı arasındaki farkı gösteren $E M B I+T R$ değiişkeni, Türkiye için ülke risk priminin bir ölçütüdür. $E M B I+T R$ 'nin yükseldiği dönemlerde Türkiye'nin ülke risk primi ve Türkiye'ye yönelik risk algısı artmakta ve buna bağlı olarak sermaye akımları yavaşlamaktadır. Tam tersine, $E M B I+T R$ 'nin düştüğü dönemlerde Türkiye'nin ülke risk primi ve Türkiye'ye yönelik risk algısı azalırken, Türkiye'ye yönelik sermaye akımları hızlanmaktadır. Bu çerçevede $E M B I+T R$ 'nin arttığı dönemlerde $B S I$ 'nın düşme eğiliminde olması, ülke risk priminin düştüğü dönemlerde ise $B S I$ 'nın yükselme eğiliminde olması beklenmektedir. Çalışmada $E M B I+T R$ değişkeni Borensztein vd. (2001), Stone vd. (2009), De Nicolò ve Ivaschenko (2009) ve Krušković ve Maričić (2014)'den hareketle logaritmik farkı alınarak kullanılmaktadır.

YPE'lerde döviz kuru hareketleri hem ülke risk primi şoklarının reel ekonomiye olan etkilerini yansıttığı hem de bankacılık sisteminin bilânçosu ve finansal istikrar açısından önemli bir değişken olduğu için, çalışmada TÜFE bazlı reel efektif döviz kuru (REER) değişkenine yer verilmektedir. REER'deki artış, TL'nin USD karşısında aşırı değerlendiği ya da değer kazandığı anlamına gelirken, REER'deki düşüş ise TL'nin USD karşısında değer kaybettiği anlamına gelmektedir. Çalışmada Jin (2003), Gali ve Monacelli (2005), Burstein vd. (2005), Haussman vd. (2006) ve Gadanecz ve Mehrotra (2013)'den hareketle REER değiş̧keni logaritmik farkı alınarak kullanılmaktadır.

Enflasyon hedeflemesi uygulayan YPE merkez bankaları ülke risk primi şoklarının döviz kuru yoluyla yaratabileceği enflasyonist etkileri önleyebilmek için, ülke risk primi şokları karşısında politika faiz oranını artırarak tepki vermeyi tercih etmektedirler. Bu durum göz önünde bulundurularak çalışmada politika faiz oranı için, Clarida, Gali ve Gertler (1998), Peersman (2002), Berument (2007), Alper ve Torul (2008), Aslaner vd. (2014), Tunç ve Yavaş (2015)'dan hareketle bankalar arası para piyasası gecelik repo faiz oranı (INTON) vekil/gölge değişken (proxy variable) olarak kullanılmaktadır. 
Varlık, S. (2017), "Ülke Risk Primi Şokunun Bankacılık Sisteminin Sağlamlığına Etkisi:

SVAR Modeli Çerçevesinde Türkiye Örneği”, Sosyoekonomi, Vol. 25(33), 103-126.

Türkiye'de bankacılık sektörünün aktif büyüklüğünün tüm finansal sektör içindeki payının yüksek düzeyde olduğu bilinmektedir ${ }^{4}$. Bununla birlikte ülke risk primi şoklarının sermaye akımlarıyla yakın bir ilişki içinde olduğu göz önünde bulundurulduğunda, finansal sektörün varlık fiyatlarının ülke risk primi şokuna verdiği tepkinin bankacılık sisteminin sağlamlığı açısından önemli olduğu düşünülmektedir. Çünkü ülke risk primindeki değişime bağlı olarak finansal sektörün ihraç ettiği hisse senetlerine olan talep değişebilir. Bu nedenle çalışmada finansal sektörün varlık fiyatlarını temsil ettiği düşünülerek Borsa İstanbul finansal endeksinin (BISTFIN) kullanılmasına karar verilmiştir. Çalışmada Campbell (1998), Kaminsky ve Schmukler (2002) ve Takáts (2010)'dan hareketle BISTFIN değişkeni logaritmik farkı alınarak kullanılmaktadır.

Çalışmada bankacılık sektörünün bilânço yapısının sağlamlığının reel ekonomiye olan yansımaları kredi-mevduat faiz farkı (kredi faiz marjı; SPREAD) değişkeni ile incelenmektedir. SPREAD değişkeni kredi standartları, kredi piyasasında yaşanan gelişmeler ve dolayısıyla bankacılık sektörünün aracılık faaliyetleri hakkında bilgi sağlamaktadır. SPREAD'in kredi faizleri yönünde genişlemesi bankaların kredi vermek konusunda daha az istekli olduklarını ve kredi standartlarını sıkılaştırdıklarını, yani kredi verme (riski alma) iştahlarının azaldığını gösterirken, SPREAD'in azalması ise bankaların kredi vermek konusunda daha istekli olduklarını ve kredi standartlarını gevşettiklerini göstermektedir. Bu bakımdan SPREAD değişkeninin ekonominin genişleme dönemlerinde azalması, daralma dönemlerinde ise kredi faizleri yönünde genişlemesi beklenmektedir (Binici vd., 2013; TCMB, 2012; Ünsal, 2013). Dolayısıyla SPREAD değişkeni bankaların aracılık maliyetlerindeki değişim hakkında bilgi vermektedir. İktisat yazınında bankacılık kesiminin faiz marjı hesaplanırken bankaların faiz gelirleri ile faiz giderleri arasındaki farkın (net faiz gelirlerinin) bankaların aktif büyüklüklerine oranı veya kredi-mevduat faiz fark1 kullanılmaktadır. Faiz marjı için Ho ve Saunders (1981), Angbanzo (1997), Demirgüç-Kunt ve Huizinga (1999), Saunders ve Schumacher (2000) ve Maudos ve Fernandez de Guevara (2004) net faiz geliri/toplam aktif oranını kullanırlarken, Zarruk ve Madura (1992), Wong (1997), Curdia ve Woodford (2010) ise kredi-mevduat faiz oranı farkını kullanmaktadırlar. Türkiye için yapılan çalışmalarda faiz marjı değişkeni için; Kaya (2002), Erol (2007), Aysan vd. (2010) ve Doğru (2011)'nun net faiz gelirleri/toplam aktif oranını kullandıkları görülmektedir. Faiz marjı için kredi-mevduat faiz farkı değişkeninin yer aldığı çalışmalarda; Kaya (2001) Emlak Bankası'nın ticari kredi faiz oranı ile yıllık vadede ortalama mevduat faiz farkı değişkenini kullanırken, Tunay ve Silpar (2006) aylık olarak hesaplanan bir yıllık kredi faizleri ile bir yıllık mevduat faizleri arasındaki farkı kullanmaktadırlar. Özdinçer ve Özyıldırım (2010) ise banka bazında (17 bankanın) kamuoyuna açıklanan kredi faizleri ile mevduat faizleri arasındaki farkı kullanmaktadırlar. TCMB (2012) kredi-mevduat faiz fark1 için iki alternatif değişkenin kullanılabileceğini önermektedir. Bunlar; (i) TL cinsinden

4 TCMB (2005b) verilerine göre 2004 yllında \%91,4 olan bu oran, Türkiye Bankalar Birliği (2015) verilerine göre 2015 yılında \%86 düzeyine düşmüştür. Bu durum bankacılık kesiminin finansal sektör içindeki ağırlığının devam ettiğini göstermektedir. 
Varlık, S. (2017), “Ülke Risk Primi Şokunun Bankacılık Sisteminin Sağlamlığına Etkisi: SVAR Modeli Çerçevesinde Türkiye Örneği”, Sosyoekonomi, Vol. 25(33), 103-126.

ağırlıklı ortalama toplam kredi faizi ile TL cinsinden ağırlıklı ortalama toplam mevduatların faiz farkı (toplam faiz marjı) ve (ii) tüketici kredileri ile tasarruf mevduatı faiz farkıdır. Binici vd. (2013) ise, faiz oranlarının vade yapılarını dikkate alarak TL cinsinden ticari krediler ile TL cinsinden üç aylık mevduatlar arasındaki faiz farkını kullanmaktadırlar. Bu çalışmada, kredi-mevduat faiz farkı için, daha kapsamlı olduğu düşünülerek, TCMB (2012)'den hareketle, TL cinsinden ağırlıklı ortalama toplam kredi faiz oranı ile TL cinsinden ağırlıklı ortalama toplam mevduat faiz oranı farkına (toplam faiz marjı) yer verilmektedir.

Öte yandan Türkiye'nin de içinde bulunduğu YPE'lerde makro finansal değişkenler uluslararası faiz oranlarından (Uribe \& Yue, 2006; Mackowiak, 2007; Izquerdo vd., 2008; Di Giovanni \& Shambaugh, 2008), petrol fiyat hareketlerinden (Mussa, 2000; Harris vd., 2009) ve küresel risk iştahında meydana gelen değişimlerden (Illing, 2004; Özatay vd., 2009; Matsumoto, 2011; Choi, 2015) etkilenmektedir. Bu nedenle çalışmada uluslararası faiz oranları için ABD'nin iki yıllık Hazine tahvillerinin faiz oranı (USTWO), petrol fiyatları için brent petrolün varil fiyatının logaritmik farkı $(O I L)$, küresel risk iştahı için (VIX) endeksinin ${ }^{5}$ logaritması dışsal değişkenler olarak kullanılmaktadır.

Çalışmada, EMBI+TR ve OIL değişkenlerine Thomson Reuters Data Stream veri tabanından, USTWO değişkenine Federal Reserve Economic Data (FRED) sisteminden, VIX endeksine Chicago Board Options Exchange (CBOE) veri tabanından, INTON, REER, BISTFIN ve SPREAD değişkenlerine TCMB'nin Elektronik Veri Dağıtım Sistemi'nden (EVDS) ulaşılmıştır. Bununla birlikte BSI oluşturulurken kullanılan değişken seti ise BDDK'dan elde edilmiştir.

VAR analizinin yapıldığı çalışmalarda durağan olmayan serilerin kullanılması, katsayı tahminlerinin sapmalı ve tutarsız olmasına ve dolayısıyla sahte regresyon sorununa neden olabilmektedir. Bu nedenle çalışmada, Enders (1995)'den hareketle, düzeyde durağan olmayan serilerin durağanlaştırılarak kullanılmalarına karar verilmiştir. Çalışmada öncelikle değişkenlerin durağanlıkları yapılsal kırılmaları dikkate almayan Augmented Dickey-Fuller (ADF; 1979) ve yapılsal kırılmaların dışsal olarak bilindiği varsayımına dayanan PhillipsPerron (PP; 1988) birim kök testleri kullanılarak sınanmaktadır. Ardından serilerdeki kırılma noktasını içsel olarak tahmin eden ve böylece değişkenlerdeki yapısal kırılmayı dikkate alan Zivot-Andrews (ZA; 1992) birim kök testi yapılmıştır. ZA tek kırılmalı birim kök testidir. Dolayısıyla serilerde birden fazla kırılmanın olabileceği dikkate alınarak Lee ve Strazicich (2003) tarafından geliştirilen iki kırılmalı LM birim kök testi de uygulanmıştır. Sen (2003), iki kırılmalı LM birim kök testlerinde düzeyde ve eğimde kırılmaya izin veren Model C'nin alternatif modellerden daha üstün olduğunu belirtmektedir. Bu nedenle çalışmada Model C

5 VIX endeksi küresel risk iştahının bir ölçütüdür. VIX endeksindeki artışlar küresel risk iştahının düştügü, küresel finansal piyasalarda belirsizliklerin arttı̆̆l ve küresel likiditenin daraldı̆̆l dönemleri, endeksteki düşüşler ise, küresel risk iştahının arttığl, küresel finansal piyasalarda belirsizliklerin azaldığl ve buna bağlı olarak küresel likiditenin genişlediği dönemleri göstermektedir. 
için iki kırılmalı LM birim kök testi yapılmıştır. Birim kök testi sonuçları Ek-2'de yer alan tablolarda sunulmaktadır. ADF ve PP birim kök testlerinin sonuçları Tablo 2'de, ZA tek kırılmalı birim kök testi sonuçları Tablo 3'te ve iki kırılmalı LM birim kök testi sonuçları ise Tablo 4'de gösterilmektedir'.

ADF ve PP birim kök testlerinin sonuçlarına göre, INTON ve USTWO değişkenleri için "birim kök vardır" şeklindeki boş hipotez reddedilememektedir. Farklı bir ifade ile bu testler sonucunda INTON ve USTWO dişındaki diğer değişkenlerin $I(0)$ oldukları bulgusuna ulaşılmaktadır. Çalışmada ADF ve PP birim kök testlerinden elde edilen bulgular, ZA birim kök testi bulguları ile desteklenmektedir. ZA birim kök testi bulgularına göre Model A ve Model C'de sadece INTON ve USTWO değişkenleri için hesaplanan t-istatistiği değerleri kritik t değerlerinden küçük bulunduğu için, “yapısal kırılmayla birim kök vardır” şeklindeki boş hipotez reddedilememektedir. Ayrıca çalışmada iki kırılmalı LM birim kök testi uygulanarak Model C'den elde edilen bulgular, yine INTON ve USTWO değişkenleri için "yapısal kırılmayla birim kök vardır" şeklindeki boş hipotezin reddedilemediğini göstermektedir. çalışmada uygulanan farklı birim kök testlerinin sonuçlarına göre; düzeyde durağan olmayan INTON ve USTWO serilerinin birinci dereceden farkları alındığında durağanlıkları sağlanmaktadır. Bu nedenle çalışmada bu değişkenlerin birinci dereceden farkları alınarak kullanılmalarına karar verilmektedir.

\section{SVAR Modeli ve Çalışmada Kullanılan Modelin Tanımlama Yapısı}

SVAR modeli, Litterman (1979), Sims (1980) ve Doan vd. (1984) tarafindan geliştirilen standart VAR modeline yönelik eleştiriler üzerine geliştirilmiştir. Standart VAR modelinde hata terimlerine getirilen üçgensel yapının (recursive structure) iktisat teorisiyle uyumlu olmadığı durumlarda şokların etkisi tanımlanamadığı gibi, etki-tepki bulgularının değişkenlerin model içindeki sıralamasına duyarlı olmasına (Choleski ayrıştırmasında) bağlı olarak etki-tepki fonksiyonlarının grafikleri de açıklayıcı olmayabilir. Bu nedenle Cooley ve Leroy (1985) standart VAR modelini politika değerlendirmesi yapmak için uygun bir model olarak görmemektedir. Sims (1986), Bernanke (1986), Shapiro ve Watson (1988) ve Christiano ve Eichenbaum (1992) tarafindan geliştirilen SVAR modelinde standart VAR modelinin bu yetersizlikleri, modele iktisat teorisine uygun kısıtlar konularak aşılmaktadır. $\mathrm{Bu}$ sayede SVAR modeli politika değerlendirmelerinin yapılabilmesine olanak sağlamaktadır.

Standart bir $\operatorname{VAR}(p)$ modeli (1) numaralı eşitlikte gösterilmektedir.

$$
A X_{t}=B(L) X_{t-1}+\varepsilon_{t}
$$


Burada $X_{t}, n \times 1$ boyutlu içsel değişken vektörüdür. Makro iktisadi değişkenlerden oluşmaktadır. $X_{t-1}$ ise bu değişkenlerin gecikme vektörüdür. Modeldeki eş zamanlı ilişkileri gösteren $A$ matrisi içsel değişkenlere ait yapısal katsayılardan oluşmaktadır. B(L), gecikme operatöründe $p$ derecesinden matrise ait polinomu ifade etmektedir. $\varepsilon_{t}, n \times 1$ boyutlu hata terimi vektörüdür ve birbiriyle ilişkisiz yapısal şokları göstermektedir.

(1) numaralı eşitlikte gösterilen standart $\operatorname{VAR}(p)$ modeli indirgenmiş biçimde de yazılabilir.

$X_{t}=C(L) X_{t-1}+\mathrm{e}_{t}$

(2) numaralı eşitlikte yer alan $C(L)=A^{-1} B(L)$ ve $e_{t}=A^{-1} \varepsilon_{t} \quad$ olarak tanımlanmaktadır. Burada indirgenmiş modelin hata terimlerinin $\left(e_{t}\right)$ kovaryans matrisi ile yapısal hataların $\left(\varepsilon_{t}\right)$ kovaryans matrisi arasındaki ilişki, indirgenmiş VAR modeline göre tahmin edilen hata terimlerinin varyans-kovaryans matrisi $\left(\Sigma_{e}\right)$ ile kurulmaktadir ${ }^{7}$.

$\mathrm{Bu}$ noktada değişkenlerin yapısal şoklar karşısında gösterdiği dinamik tepkileri ölçebilmek için etki-tepki fonksiyonlarına başvurulmaktadır. Etki-tepki fonksiyonları (3) numaralı eşitlikte gösterilmektedir. (3) numaralı eşitlikte yer alan $\theta_{i}, X_{t}$ 'nin yapısal şoklara verdiği tepkiyi açıklayan $n \times n$ boyutundaki katsayılar matrisidir.

$$
X_{t}=\theta(L) \varepsilon_{t}=\sum_{i=0}^{\infty} \theta_{i} L^{i} \varepsilon_{t}
$$

İndirgenmiş VAR modelinin hata terimlerinde ortaya çıkabilecek yapısal şokların belirlenebilmesi için, içsel değişkenlere ait yapısal katsayılardan oluşan $A$ matrisine, iktisat teorisine uygun olarak $\frac{\left(n^{2}-n\right)}{2}$ adet kısıt konulması gerekmektedir. $\varepsilon_{t}=A e_{t}$ ilişkisinden hareketle yapısal şoklar için kovaryans matrisi, kısıt matrisi ile indirgenmiş VAR modelinin hata terimlerinin kovaryans matrisinin çarpımına eşittir. Çalışmada $6 \times 1$ büyüklüğündeki içsel değişken vektörü $X_{t}=(E M B I+T R, R E E R, B I S T F I N, I N T O N, B S I, S P R E A D)$ şeklindedir. Buna göre çalışmada kullanılan 6 içsel değişken için söz konusu ilişki (4) numaralı eşitlikte tanımlanmaktadır.

$$
\left[\begin{array}{c}
\varepsilon^{E M B I+T R} \\
\varepsilon^{R E E R} \\
\varepsilon^{B I S T F I N} \\
\varepsilon^{I N T O N} \\
\varepsilon^{B S I} \\
\varepsilon^{S P R E A D}
\end{array}\right]=\left[\begin{array}{llllll}
1 & 0 & 0 & 0 & 0 & 0 \\
* & 1 & 0 & * & 0 & 0 \\
* & * & 1 & * & 0 & 0 \\
* & 0 & 0 & 1 & 0 & 0 \\
* & * & * & * & 0 & 0 \\
* & * & * & * & 1
\end{array}\right]\left[\begin{array}{c}
u_{E M B I+T R} \\
u_{R E E R} \\
u_{B I S T F I N} \\
u_{I N T O N} \\
u_{B S I} \\
u_{S P R E A D}
\end{array}\right]
$$

7 Indirgenmiş VAR modeline göre tahmin edilen hata terimlerinin kovaryans matrisi $\Sigma_{e}=A^{-1} \sum_{\varepsilon} A^{\prime-1}$ olarak ifade edilmektedir. $\Sigma_{e}$ simetriktir. Bu nedenle $\Sigma_{e}$ matrisinin $\left(n^{2}+n\right) / 2$ sayıda farkl elemanı bulunmaktadir. $\Sigma_{e}$ matrisi birim matrise dönüştürüldüğünde $\Sigma_{e}=A^{-1} A^{\prime-1}$ olarak yazılabilir. 
Yapısal şoklar $\varepsilon_{t}=\left(\varepsilon_{t}^{E M B I+T R}, \varepsilon_{t}^{R E E R}, \varepsilon_{t}^{B I S T F I N}, \varepsilon_{t}^{I N T O N}, \varepsilon_{t}^{B S I}, \varepsilon_{t}^{S P R E A D}\right)$ olarak ifade edilmektedir. Yapısal şoklar arasında ilişki yoktur. Buna göre; $\varepsilon_{t}^{E M B I+T R}$ ülke risk primi

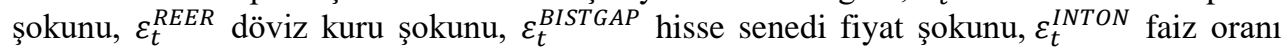
şokunu ve $\varepsilon_{t}^{B S I}$ bankacılık sağlamlık endeksi şokunu ve $\varepsilon_{t}^{S P R E A D}$ kredi-mevduat faiz farkı şokunu göstermektedir ${ }^{8}$. Benzer şekilde $u_{E M B I+T R}, u_{R E E R}, u_{B I S T F I N}, u_{I N T O N}, u_{B S I}$ ve $u_{S P R E A D}$ ise indirgenmiş VAR hata terimlerini göstermektedir.

Çalışmada 6 değişkenli SVAR modeli için, içsel değişkenlere ait yapısal katsayılardan oluşan $A$ matrisine 15 adet kısıt konulmuştur. $E M B I+T R$ 'nin modelde yer alan diğer içsel değişkenlerden eş zamanlı olarak etkilenmediği, ancak bu değişkenleri eş zamanlı olarak etkilediği varsayılmıştır $\left(a_{21} \neq a_{31} \neq a_{41} \neq a_{51} \neq a_{61} \neq 0\right)$. REER şokunun BISTFIN'i, BSI'yı ve SPREAD'i eş zamanlı olarak etkilemesi beklendiği için, sırasıyla $a_{32} \neq 0, a_{52} \neq 0$ ve $a_{62} \neq 0$ olarak belirlenmiştir. BSI'nın ve SPREAD'in BISTFIN'de meydana gelen şoklardan eş zamanlı olarak etkilendiği düşünülerek $a_{53} \neq 0$ ve $a_{63} \neq$ 0 alınmıştır. Bununla birlikte INTON'nin, $E M B I+T R$ dışındaki diğer tüm içsel değişkenleri eş zamanlı etkilediği düşünülerek $a_{24} \neq a_{34} \neq a_{54} \neq 0$ ve $a_{64} \neq 0$ olarak kabul edilmiştir. Ayrıca çalışmada $B S I$ değişkeninin SPREAD dışındaki diğer tüm değişkenlerden eş zamanlı olarak etkileneceği, SPREAD'i ise eş zamanlı olarak etkileyeceği beklendiği için $a_{65} \neq 0$ olarak belirlenmiştir. Son olarak SPREAD'in kendisi dışındaki diğer tüm içsel değişkenlerden eş zamanlı olarak etkilendiği varsayılmıştır.

Çalışmada ayrıca varyans ayrıştırması yöntemi kullanılarak BSI ve SPREAD değişkenlerinin her birindeki değişimin \% kaçının kendisinden, \% kaçının çalışmada kullanılan diğer değişkenlerden kaynaklandığı incelenmektedir. Böylece şok süresince $B S I$ 'nin ve SPREAD'in varyansında meydana gelen değişmeye, modelde kullanılan diğer değişkenlerin yaptığı katkıları ölçmek mümkün olabilecektir.

Varyans ayrıştırması yöntemi ile sistemdeki herhangi bir değişkende meydana gelen bir şokun diğer değiş̧kenin ileriye dönük hata terimi varyansında neden olduğu yüzde değişim ölçülebilmektedir. Dolayısıyla varyans ayrıştırması, bir değişkenin kendisinden kaynaklanan şoklar karşısında diğer değişkenin şokları ile olan oransal hareketlerini göstermektedir.

Modelin $n$ dönem sonrası için tahmin hatası $X_{t+n}-E\left(X_{t+n}\right)$ olarak ifade edildiğinde, $x_{t+n}$ serisinin $n$ dönem sonraki öngörü hata varyansı $\sigma_{x}^{2}(n)$ şu şekildedir:

$$
\begin{aligned}
& \sigma_{x}^{2}(n)=\sigma_{y}^{2}\left[\phi_{11}(0)^{2}+\phi_{11}(1)^{2}+\cdots+\phi_{11}(n-1)^{2}\right]+\sigma_{z}^{2}\left[\phi_{12}(0)^{2}+\phi_{12}(1)^{2}+\cdots+\right. \\
& \left.\phi_{12}(n-1)^{2}\right]
\end{aligned}
$$

8 Çalışmada ülke risk primi şoku karşısında modelde yer alan diğer değişkenlerin verdiği tepkiler incelenmektedir. 
(5) numaralı eşitlikte yer alan $\phi_{j k}(i)^{2}$ şoklar karşısında $i$ dönem sonraki tepkileri göstermektedir. $\phi_{j k}(i)^{2}$ 'nin değeri hiçbir zaman negatif olmadığı içi, $n$ arttıkça tahmin hatasının varyansı da artmaktadır. Bu noktadan hareketle, $n$ dönem sonraki tahmin hatasının varyansı şoklara göre ayrıştırılabilir. $\varepsilon_{\mathrm{yt}}$ ve $\varepsilon_{\mathrm{zt}}$ şokları nedeniyle her bir tahmin hata varyansı şu şekildedir:

$$
\begin{aligned}
& \frac{\sigma_{y}^{2}\left[\phi_{11}(0)^{2}+\phi_{11}(1)^{2}+\cdots+\phi_{11}(n-1)^{2}\right]}{\sigma_{x}^{2}(n)} \\
& \frac{\sigma_{z}^{2}\left[\phi_{12}(0)^{2}+\phi_{12}(1)^{2}+\cdots+\phi_{12}(n-1)^{2}\right]}{\sigma_{x}^{2}(n)}
\end{aligned}
$$

\section{Etki-Tepki ve Varyans Ayrışıırması Analizlerinin Ampirik Bulguları}

SVAR analizinde öncelikle modelin uygun gecikme uzunluğu belirlenmektedir. Çalışmada tahmin edilen modelin uygun gecikme uzunluğunun Sequential Modified LR Test Statistics (LR), Final Prediction Error (FPE), Akaike Information Criterion (AIC), Schwarz Information Criterion (SC) ve Hannan-Quinn (HQ) kriterlerine göre 1 olduğu görülmüştür. Ancak, modelin hata terimlerinin birbirleri ile ilişkili olup olmadıklarını test etmek amacıyla uygulanan Autocorrelation LM Testi sonuçları, 3. gecikme uzunluğunda otokorelasyon probleminin yaşanmadığını göstermektedir. Bu nedenle çalışmada model için belirlenen uygun gecikme sayısı, 3 olarak kabul edilmiştir. Diğer taraftan, hata terimlerinin varyansının tüm örneklem için sabit olup olmadığını test etmek amacıyla uygulanan White Testi'nin sonuçlarına göre, 3. gecikmede değişen varyans (heteroskedasticity) problemiyle karşılaşılmamaktadır. Ayrıca, AR karakteristik polinomunun ters köklerinin birim çember içinde yer almaları, modelin bütün olarak durağan olduğunu yansıtmaktadır. Bununla birlikte modelde bir bütün olarak yapısal kırılmanın olup olmadığını test etmek amacıyla CUSUM ve CUSUM-Square Testleri uygulanmıştır. Test sonuçları modelde bir bütün olarak yapısal kırılmanın olmadığını göstermektedir. Buna göre uzun dönem modelinin istikrarlı ve seçilen model spesifikasyonunun uygun olduğunu söylemek mümkündür. Dolayısıyla, yapılan testler, çalışmada tahmin edilen SVAR modelinde yapısal bir sorun bulunmadığını göstermektedir.

Ek-3'de yer alan Grafik-2'de, ülke risk primine verilen bir standart sapma yapısal şok karşısında modelde yer alan diğer değişkenlerin verdikleri tepkiler gösterilmektedir. Ülke risk primine $(E M B I+T R)$ verilen bir standart sapma pozitif şoka değişkenin kendisinin verdiği tepkinin sadece birinci ay istatistiksel olarak anlamlı bulunması, ülke risk primi şokunun bir ay sürdüğünü göstermektedir. Bir standart sapma ülke risk primi şokuna reel efektif döviz kurunun (REER) verdiği tepki, beklendiği gibi düşüş yönünde (TL'de değer kaybı) gerçekleşmektedir. Ülke risk primi şoku karşısında $R E E R$ 'in düşüş yönünde verdiği tepki ilk iki ay boyunca istatistiksel olarak anlamlıdır. Benzer olarak, ülke risk priminde meydana gelen bir standart sapma şok karşısında, finansal sektörün hisse senedi fiyat endeksinin $(B I S T F I N)$ verdiği tepki beklendiği gibi düşüş yönünde gerçekleşmektedir. Çalışmada BISTFIN endeksinin düşerek verdiği bu tepkinin ilk iki ay boyunca istatistiksel olarak anlamlı olduğu bulgusu elde edilmektedir. Diğer taraftan, TCMB'nin ülke risk primi şokuna politika faiz oranını (INTON) artırarak verdiği tepki nokta tahmin olarak ilk dört ay 
Varlık, S. (2017), “Ülke Risk Primi Şokunun Bankacılık Sisteminin Sağlamlığına Etkisi:

SVAR Modeli Çerçevesinde Türkiye Örneği”, Sosyoekonomi, Vol. 25(33), 103-126.

boyunca artış yönünde gerçekleşmektedir. Ancak, INTON'deki bu artış sadece ikinci ve üçüncü aylarda istatistiksel olarak anlamlıdır. Bununla birlikte, ülke risk primi şokuna INTON'nin verdiği tepkinin, REER'in ve BISTFIN'in verdikleri tepkilerden daha büyük olduğu görülmektedir. Ülke risk priminde meydana gelen bir standart sapma şoka bankacılık sağlamlık endeksinin ( $B S I)$ verdiği tepki düşüş yönünde gerçekleşmektedir. BSI'nın ülke risk primi şokuna verdiği tepkinin, nokta tahmin olarak ilk dört ay boyunca düşüş yönünde olduğu ve bunun sadece birinci ayında istatistiksel olarak anlamlı olduğu bulgusuna ulaşılmaktadır. Son olarak, ülke risk priminde meydana gelen bir standart sapma şok karşısında kredi-mevduat faiz farkı (SPREAD) değişkeninin verdiği tepki artış yönündedir. Çalışmada SPREAD değişkeninin ülke risk primi şokuna artış yönünde verdiği tepkinin ilk sekiz ay boyunca istatistiksel olarak anlamlı olduğu bulgusuna ulaşılmaktadır ${ }^{9}$.

Modelin artıklarının analizinde kullanılan bir diğer yöntem, bir değişkenin hata teriminde meydana gelen şokun diğer değişkenler tarafından açıklanma oranını gösteren varyans ayrıştırmasıdır (variance decomposition) (Enders, 1995). Çalışmada BSI ve SPREAD değişkenlerine ait varyans ayrıştırması bulguları Ek-3'te yer alan Tablo 5'te sunulmaktadır.

BSI'nın varyans ayrıştırması bulgularına göre, altıncı gecikme döneminde BSI'nın öngörü hatasında meydana gelen değişimin kendi iç dinamikleri tarafından açıklanma oranının \%84 düzeyinde olduğu ve ilerleyen gecikme dönemlerinde BSI şokunun kendi iç dinamikleri tarafından açıklanma oranı düşerken, INTON dışındaki diğer değişkenler tarafından açıklanma oranının yükseldiği görülmektedir. $B S I$ şokunun kendi iç dinamikleri tarafından açıklanma oranının yirmi dördüncü gecikme döneminde yaklaşık olarak \%78 düzeyine düştüğü, buna karşın $B S I$ şokunun $S P R E A D, E M B I+T R, B I S T F I N$ ve REER değişkenleri tarafından açıklanma oranının sırasıyla \%8.2, \%5, \%4.3 ve \%4.2 düzeylerine yükseldiği bulgusuna ulaşılmaktadır.

SPREAD değişkeninin varyans ayrıştırması bulguları, altıncı gecikme döneminde $S P R E A D$ 'in öngörü hatasında meydana gelen değişimin $\% 52$ oranında kendi iç dinamikleri tarafından açıklandığını göstermektedir. Altıncı gecikme döneminde $E M B I+T R$ ve REER değişkenlerinin SPREAD şokunu açıklama oranları yaklaşık olarak \%20 düzeylerinde gerçekleşmiştir. İlerleyen gecikme dönemlerinde SPREAD şokunun kendi iç dinamikleri

9 Öte yandan etki-tepki analizi sonuçlart incelendiğinde EMBI+TR 'de meydana gelen bir standart sapma yapısal şok karşısında değişkenin kendisinin verdiği tepkinin üçüncü ayda azalış yönünde ve istatistiksel olarak anlamlı olduğu görülmektedir. REER değişkeninin EMBI+TR'deki bu düşüş karşısında üçüncü ayda artarak verdiği tepkinin istatistiksel olarak anlamlı olduğu bulgusuna ulaşılmaktadır. Buna göre ülke risk primindeki düşüşe TL değer kazanarak tepki vermektedir. Yine aynı şekilde, BISTFIN değişkeni EMBI+TR'deki düşüşe üçüncü ayda artarak tepki vermekte ve bu tepki sınırda istatistiksel olarak anlamlı bulunmaktadır. EMBI+TR'deki düşüş karşısında INTON değişkeninin nokta tahmin olarak dördüncü aydan itibaren düşerek tepki verdiği, BSI'nın ise nokta tahmin olarak beşinci aydan itibaren artarak tepki verdiği görülmektedir. Ancak, bu değişkenlerin EMBI+TR'de meydana gelen düşüşe verdikleri tepkiler istatistiksel olarak anlaml bulunmamaktadır. 
tarafından açıklanma oranı düşerken, $B S I$ tarafından açıklanma oranının belirgin bir biçimde yükseldiği görülmektedir. Yirmi dördüncü gecikme döneminde $S P R E A D$ şokunun $B S I$ tarafından açıklanma oranının \%20.4 düzeyine yükseldiği ve $E M B I+T R$ ve REER tarafından açıklanma oranlarının ise, yaklaşık olarak, sırasıyla \%18 ve \%17 düzeylerinde gerçekleştiği bulgusuna ulaşılmaktadır. Bununla birlikte yirmi dördüncü gecikme döneminde BISTFIN ve INTON değişkenleri SPREAD şokunu toplamda yaklaşık olarak $\% 7$ gibi sınırlı bir düzeyde açıklamaktadır.

Kısacası, varyans ayrıştırması bulgularına göre bankacılık sektörünün bilânço yapısında meydana gelen yapısal şokların açıklanmasında ülke risk primi, döviz kuru ve kredi-mevduat faiz farkı değişkenlerinin etki gücü sınırlı bir düzeydedir. Buna karşın, kredimevduat faiz farkı değişkeninde meydana gelen yapısal şokların açıklanmasında ülke risk primi, döviz kuru ve bankacılık sağlamlık endeksi değişkenlerinin etki etki gücünün yüksek düzeyde olduğu görülmektedir.

\section{Sonuç}

Türkiye gibi YPE’lerde bankacılık sektörünün bilânço yapısı, sermaye akımlarıyla ilişkili olan ülke risk primindeki artışlardan olumsuz biçimde etkilenmektedir. Çalışmada Ocak 2004-Haziran 2015 döneminde, Türkiye'nin ülke risk priminde meydana gelen yapısal şokların bankacılık sektörünün bilânçosunun sağlamlığını ve aracılık faaliyetlerini nasıl etkilediği SVAR modeli kullanılarak incelenmiştir.

Etki-tepki analizinden elde edilen bulgulara göre, ülke risk priminde meydana gelen bir standart sapma pozitif yapısal şok karşısında reel efektif döviz kuru ve finansal hisse senedi fiyatları düşmekte, politika faiz oranı yükselmekte, bankacılık sağlamlık endeksi düşmekte ve kredi-mevduat faiz farkı (spread) yükselmektedir. Çalışmanın bulguları bankacılık sektörünün bilânço yapısının ülke risk primi şoklarından sadece bir ay gibi kısa bir süre olumsuz yönde etkilendiğini göstermektedir. Bu nedenle elde edilen bulgular ülke riskine yönelik olumsuz algılamalar karşısında bankacılık sektörünün bilânço yapısının güçlü olduğunu yansıtmaktadır. Diğer taraftan kredi-mevduat faiz farkı değişkeninin ülke risk primi şokuna yükselerek verdiği tepkinin sekiz ay gibi uzun bir süre devam etmesi, ülke risk primi şokunun olumsuz etkilerinin bankacılık sektörü tarafindan faiz kanalıyla reel ekonomiye yansıtıldığı şeklinde yorumlanabilir. Farklı bir ifade ile bankacılık sektörünün bilânço yapısı ülke risk priminde meydana gelen değişimlerden görece daha sınırlı bir düzeyde etkilenmesine rağmen, şokun etkilerinin faiz kanalıyla reel ekonomiye daha uzun süre yansıtıldı̆̆ 1 söylenebilir. Bununla birlikte çalışmada varyans ayrıştırmasından elde edilen bulguların, etki-tepki analizi bulgularını desteklediği sonucuna ulaşılmıştır.

Çalışmada elde edilen bulgulardan hareketle, Türkiye özelinde, dışsal kırılganlık probleminin bankacılık sektörü kanalıyla yurtiçi ekonomiye yansımalarını azaltabilecek politikalar çerçevesinde; (i) bankacılık sektörünün bilânço yapısının sağlamlığını koruyacak düzenleme ve denetim faaliyetleri sürdürülmesi, (ii) Türkiye'nin ülke risk primindeki artışları sınırlayacak şekilde makro finansal istikrarı sağlayan politikaların uygulanması önerilebilir. Bu kapsamda faiz politikasının konjonktür karşıtı makro ihtiyati araçlarla 
Varlık, S. (2017), "Ülke Risk Primi Şokunun Bankacılık Sisteminin Sağlamlığına Etkisi:

SVAR Modeli Çerçevesinde Türkiye Örneği”, Sosyoekonomi, Vol. 25(33), 103-126.

desteklenmesine ve mali disiplinin korunmasına bağlı olarak, dişsal şokların bankacılık sektörünün bilânçosu üzerindeki etkilerinin azalacağı düşünülmektedir. Böylece dışsal kırılganlıkların bankacılık sektörü kanalıyla reel ekonomiye olan yansımaları hafifletilebilir.

\section{Kaynaklar}

Agénor, P.R. \& L.A. Preira da Silva (2013), "Inflation Targeting and Financial Stability: A Perspective from the Developing World", Banco Central Do Brasil Working Papers, $324,1-117$.

Akkaya, Y. \& S.R. Gürkaynak (2012), "Current Account Deficit, Budget Balance, Financial Stability and Monetary Policy: Reflections on a Gripping Episode", Iktisat Işletme ve Finans, 27(315), 93-119.

Allegret, J.P. \& A. Sand (2009), "Modeling The Impact of Real and Financial Shocks on Mercosur: The Role of The Exchange Rate Regime", Open Economies Review, 20(3), 359-384.

Alper, C.E. \& O. Torul (2008), "Oil Prices, Aggregate Economic Activity and Global Liquidity Conditions: Evidence FromTurkey”, Economics Bulletin, 17(4), 1-8.

Angbanzo, L. (1997), "Commercial Bank Net Interest Margins, Default Risk, Interest Rate Risk and Off-Balance Sheet Banking”, Journal of Banking and Finance, 21(1), 55-87.

Aslaner, O. \& U. Çıplak \& A.H. Kara \& D. Küçüksaraç (2014), "Reserve Option Mechanism: Does it Work as an Automatic Stabilizer?", CBRT Working Paper, 14/38, 1-16.

Aysan, A. \& C.H. Dalgıç \& M. Demirci (2010), "Macroeconomic, Sector Specific and Bank Specific Determinants of Net Interest Rate Margin: What Matters More for an Emerging Market Economy?", EcoMod, 259600015, <http://www.ecomod.net/sites/default/files/documentconference/ecomod2010/1254.pdf>, 24.10.2015.

Baldacci, E. \& S. Gupta \& A. Mati (2008), "Is It (Still) Mostly Fiscal? Determinants of Sovereign Spreads in Emerging Markets", IMF Working Paper, 08/259, 1-23.

Bankacılık Düzenleme ve Denetleme Kurumu (BDDK) (2004), Bankacılık Sektörü Değerlendirme Raporu, Ekim, Ankara,

<https://www.bddk.org.tr/WebSitesi/turkce/Raporlar/Finansal_Piyasalar_Raporlari/1497 Bankacilik_Sektoru_Degerlendirme_Raporu_Ekim_\%202004.pdf >, 27.09.2013.

Bankacıl1k Düzenleme ve Denetleme Kurumu (BDDK) (2010), Finansal Piyasalar Raporu, No. 20, Aralık, Ankara,

<http://www.bddk.org.tr/WebSitesi/turkce/Raporlar/Finansal_Piyasalar_Raporlari/9433f pr_aralik_2010.pdf >, 12.11.2013.

Baş̧̧ı, E. \& Ö. Özel \& Ç. Sarıkaya (2007), "The Monetary Transmission Mechanism in Turkey: New Developments", CBRT Working Paper, 07/04, 1-28.

Başçı, E. \& A.H. Kara (2011), "Financial Stability and Monetary Policy”, İktisat İşletme ve Finans, 26 (302), 9-25.

Başçı, E. \& Ö. Özel \& Ç.Sarıkaya (2007), “The Monetary Transmission Mechanism in Turkey: New Developments", CBRT Working Paper, 07/04, 1-28.

Baş̧̧, E. (2015), Türkiye Cumhuriyeti Merkez Bankası 83. Olağan Genel Kurul Toplantısı, Nisan, Ankara, <http://www.oecd-ilibrary.org/economics/oecd-economic-surveys-turkey2014_eco_surveys-tur-2014-en>, 25.05.2015.

Beck, R. (2001), “Do Country Fundamentals Explain Emerging Market Bond Spreads?”, CFS Working Paper, 02, 1-32. 
Bellas, D. \& M.G. Papaioannou \& I. Petrova (2010), "Determinants of Emerging Market Sovereign Bond Spreads: Fundamentals vs Financial Stress", IMF Working Paper, 10/281, 1-23.

Bernanke, B.S. (1986), “Alternative Explanations of the MoneyIncome Correlation”, NBER Working Paper, 1842, 1-62.

Berument, H. (2007), "Measuring Monetary Policy for a Small Open Economy: Turkey", Journal of Macroeconomics, 29(2), 411-430.

Binici, M. \& H. Erol \& A.H. Kara \& P. Özlü \& D. Ünalmış (2013), "Faiz Koridoru bir Makro İhtiyati Araç Olabilir mi?", TCMB Ekonomi Notları, 2013/20, 1-16.

Blanchard, O. (2004), "Fiscal Dominance and Inflation Targeting: Lessons From Brazil", NBER Working Paper, 10389, 1-46.

Borensztein, E. \& J. Zettelmeyer \& T. Philippon (2001), "Monetary Independence in Emerging Markets: Does the Exchange Rate Regime Make a Difference?", IMF Working Paper, 01/01, 1-49.

Burstein, A. \& M. Eichenbaum \& S. Rebelo (2005), "Large Devaluations and The Real Exchange Rate", Journal of Political Economy, 113(4), 742-784.

Calvo, A.G. (2002), "Globalization Hazard and Development Reform in Emerging Markets", Economia, 2, 1-29.

Campbell, J.Y. (1998), “Asset Prices, Consumption, and the Business Cycle”, NBER Working Paper, 6485, 1-111.

Carare, A. \& A. Popescu (2011), "Monetary Policy and Risk-Premium Shocks in Hungary: Results from a Large Bayesian VAR", IMF Working Paper, 11/259, 1-49.

Castro, C. \& J. Mencia (2014), "Sovereign Risk and Financial Stability”, Revista de Estabilidad Financiera, 26, 73-107.

Cheikh, A.G. \& N.R.SY. Amadou (2013), "U.S. Interest Rates and Emerging Market Bond Yield Spreads: A Changing Relationship?", The Journal of Fixed Income, 22(4), 48-52.

Choi, S. (2015), The Impact of VIX Shocks on Emerging Market Economies: A Flight to Quality Mechanism, <http://www.econ.ucla.edu/jobmarket/2014/ChoiPaper.pdf>, 22.09.2015.

Christiano, L.J. \& M. Eichenbaum (1992), "Current Real-Business-Cycle Theories and Aggregate Labor-Market Fluctuations", The American Economic Review, 82(3), 430-450.

Clarida, R. \& J. Gali \& M. Gertler (1998), "Monetary Policy Rules in Practice: Some International Evidence", European Economic Review, 42, 1033-1067.

Cooley, T.F. \& S.F. LeRoy (1985), “A Theoretical Macroeconometrics: a Critique”, Journal of Monetary Economics, 16(3), 283-308.

Cooper, J. (1983), "Factor Analysis: An Overview", The American Statistician, 37(2), 141-147.

Curdia, V. \& M. Woodford (2010), "Credit Spreads and Monetary Policy”, Journal of Money, Credit and Banking, 42(1), 3-35.

Çulha, O.Y. \& F. Özatay \& G. Şahinbeyoğlu (2006), “The Determinants of Sovereign Spreads in Emerging Markets”, CBRT Working Paper, 06/04, 1-43.

Davies, M. \& T. Ng (2011), "The Rise of Sovereign Credit Risk: Implications for Financial Stability", BIS Quarterly Review, September, 59-70.

De Nicolò, G. \& I. Ivaschenko (2009), "Global Liquidity, Risk Premiums and Growth Opportunities", IMF Working Paper, 09/52, 1-33. 
Demirguc-Kunt, A. \& H. Huizinga (1999), "Determinants of Commercial Bank Interest Margins and Profitability: Some International Evidence", World Bank Economic Review, 13(2), 379408.

Di Giovanni, J. \& J.C. Shambaugh (2008), "The Impact of Foreign Interest Rates on the Economy: The Role of The Exchange Rate Regime", Journal of International Economics, 74(2), 341-361.

Dickey, D.A. \& W.A. Fuller (1979), "Distribution of the Estimators for Autoregressive Time Series With a Unit Root", Journal of the American Statistical Association, 7(4), 427-431.

Doan, T. \& R. Litterman \& C. Sims (1984), "Forecasting and Conditional Projection Using Realistic Prior Distributions", Econometric Reviews, 3, 1-100.

Doğru, C. (2011), “Karlılığın Belirleyicileri Analizi: Teori ve Orta Ölçekli Bir Banka Uygulaması”, Maliye Finans Yazıları, 25(91), 47-75.

Enders, W. (1995), Applied Economic Time Series, John Wiley and Sons, Inc.

Erol, H. (2007), "Bankalarda Net Faiz Marjının Belirleyicileri, Risk Duyarlılığı ve Politika Önerileri”, Turkiye Cumhuriyet Merkez Bankası Uzmanlı Yeterlilik Tezi, <http://www3.tcmb.gov.tr/kutuphane/TURKCE/tezler/hasanerol.pdf>, 11.12.2014.

Ersel, H. \& F. Özatay (2008), "Fiscal Dominance and InflationTargeting: Lessons from Turkey", Emerging Markets Finance and Trade, 44(6), 38-51.

Favero, C.A. \& F. Giavazzi (2004), "Inflation Targeting and Debt: Lessons from Brazil”, NBER Working Paper, 10390,1-23.

Ferrucci, G. (2003), “Empirical Determinants of Emerging Market Economies' Sovereign Bond Spreads", Bank of England Working Paper, 205, 1-42.

Fouejieu, A. \& S. Roger (2013), "Inflation Targeting and Country Risk: An Empirical Investigation", IMF Working Paper, 13/21, 1-30.

Fracasso, A. (2007), "The Role of Foreign and Domestic Factors in The Evolution of the Brazilian EMBI Spread and Debt Dynamics", HEI Working Paper, 22/2007, 1-61.

Fraga, A. \& I. Goldfajn \& A. Minella (2003), "Inflation Targeting in Emerging Market Economies", NBER Working Paper, 10019, 1-50.

Gadanecz, B. \& A. Mehrotra (2013), "The Exchange Rate, Real Economy and Financial Markets", BIS Working Paper, 73, 11-23.

Gali, J. \& T. Monacelli (2005), "Monetary Policy and Exchange Rate Volatility in a Small Open Economy", The Review of Economic Studies, 72(3), 707-734.

Galindo, A.J. \& A. Izquierdo \& L. Rojas-Suárez (2010), "Financial Integration and Foreign Banks in Latin America: How Do They Impact the Transmission of External Financial Shocks?", IDB Working Paper Series, IDB-WP-116, 1-36.

Garcia-Herrero, A. \& A. Ortiz (2006), "The Role of Global Risk Aversion in Explaining Latin American Sovereign Spreads", Economia, 7(1), 125-148.

Gertler, M. \& S. Gilchrist \& F. Natalucci (2007), "External Constraints on Monetary Policy and the Financial Accelerator", Journal of Money, Credit and Banking, 39(2-3), 295-330.

Goldfajn, I. \& G. Olivares (2001), "Full Dollarization: The Case of Panama”, Economia, 1(2), 3-29. González-Rozada, M. \& E. Levy-Yeyati (2008), “Global Factors and Emerging Market Spreads”, The Economic Journal, 118(533), 1917-1936. 
Hair, J.F. \& W.C. Black \& B.J. Babin \& R.E. Anderson \& R.L. Tatham (2006), Multivariate Data Analysis, 6 th Edition, Upper Saddle River, NJ: Pearson Prentice Hall.

Harris, E.S. \& B.C. Kasman \& M. D. Shapiro \& K.D. West (2009), "Oil and The Macroeconomy: Lessons for Monetary Policy”, US Monetary Policy Forum Report, <http://research.chicagobooth.edu/igm/docs/2009USMPFReport.pdf>, 23.11.2015.

Hausmann, R. \& U. Panizza \& R. Rigobon (2006), “The Long-Run Volatility Puzzle of the Real Exchange Rate", Journal of International Money and Finance, 25(1), 93-124.

Ho, T.S. \& A. Saunders (1981), “The Determinants of Bank Interest Margins: Theory and Empirical Evidence", Journal of Financial and Quantitative Analysis, 16(04), 581-600.

Illing, G. (2004), "How to Escape Contagion in The Interest Rate Trap", Second Conference of the Monetary Stability Foundation: Financial Stability and Globalisation, <http://www.en.sfm.econ.unimuenchen.de/research/archiv_publikationen/contagion.pdf> , 08.06.2015.

International Monetary Found (IMF) (2006), Financial Soundness Indicators, <http://www.imf.org/external/pubs/ft/fsi/guide/2006/index.htm>, 25.03.2014.

Izquirdo, A. \& R. Romero \& E. Talvi (2008), "Boom and Business Cycles in Latin America: The Role of External Factors", IDB Working Paper, IDB-WP-631, 1-31.

Jin, Z. (2003), "The Dynamics of Real Interest Rates, Real Exchange Rates and the Balance of Payments in China: 1980-2002", IMF Working Paper, 03/67, 1-28.

Kaminsky, G. \& S. Schmukler (2002), "Emerging Market Instability: Do Sovereign Ratings Affect Country Risk and Stock Returns?", The World Bank Economic Review, 16(2), 171-195.

Kara, A.H. (2006), “Turkish Experience with Implicit InflationTargeting”, CBRT Working Paper, 06/03, 1-17.

Kara, A.H. (2012), "Monetary Policy in the Post-Crises Period”, Iktisat İsletme ve Finans, 27 (315), 9-36.

Kaya, Y.T. (2001), “Türk Bankacılık Sisteminde Net Faiz Marjının Modellenmesi”, BDDK Mali Sektör Politikası Dairesi Çalışma Raporları, 4.

Kaya, Y.T. (2002), “Türk Bankacılık Sektöründe Karlılığın Belirleyicileri: 1997-2000”, BDDK Mali Sektör Politikası Dairesi Çalışma Raporları, 1.

Kennedy, M. \& A. Palerm (2014), "Emerging Market Bond Spreads: The Role of Global and Domestic Factors from 2002 to 2011", Journal of International Money and Finance, 43, 70-87.

Kılınç, M. \& C. Tunç (2014), "Identification of Monetary Policy Shocks in Turkey: A Structural VAR Approach", CBRT Working Paper, 14/1423, 1-31.

Krušović, B.D. \& T. Maričić (2014), "Empirical Analysis of the Impact of Inflation Targeting on the Risk Premium", Journal of Central Banking Theory and Practice, 3(3), 87-99.

Lee, J. \& M.C. Strazicizh (2003), "Minimum Lagrange Multiplier Unit Root Test with Two Structural Breaks", The Review of Economics and Statistics, 85(4), 1082-1089.

Levy-Yeyati, E. \& T. Williams (2010), “US Rates and Emerging Market Spreads", Business School Working Papers, 2010-02.

Litteman, R.B. (1979), “Techniques of Forecasting Using Vector Autoregressions”, Federal Reserve of Minneapolis Working Paper, 115, 1-135.

Mackowiak, B. (2007), "External Shocks, U.S. Monetary Policy and Macroeconomic Fluctuations in Emerging Markets", Journal of Monetary Economics, 54(8), 2512-2520. 
Majnoni, G. \& A. Powell (2011), “On Endogenous Risk, The Amplification Effects of Financial Systems and Macro Prudential Policies", IDB Working Paper Series, IDB-WP-276, 1-25.

Mandelman, F.S. (2010), "Business Cycles and Monetary Regimes in Emerging Economies: A Role for a Monopolistic Banking Sector", Journal of International Economics, 81(1), 122-138.

Martinez, L.B. \& A. Terceño \& M. Teruel (2013), "Sovereign Bond Spreads Determinants in Latin American Countries: Before and During the XXI Financial Crisis", Emerging Markets Review, 17, 60-75.

Matsumoto, A. (2011), “Global Liquidity: Availability of Funds for Safe and Risky Assets”, IMF Working Paper, 11/136, 1-37.

Maudos, J. \& J. Fernandez de Guevara (2004), "Factors Explaining the Interest Margin in The Banking Sectors of The European Union”, Journal of Banking \& Finance, 28(9), 22592281.

Mussa, M. (2000), "The Impact of Higher Oil Prices on The Global Economy", IMF Working Paper, 00/8, 1-46.

Neumeyer, P.A. \& F. Perri (2005), "Business Cycles in Emerging Economies: The Role of Interest Rate", Journal of Monetary Economics, 52, 345-380.

Nickel, C. \& P.C. Rother \& J.C. Rülke (2009), "Fiscal Variables and Bond Spreads - Evidence from Eastern European Countries and Turkey", European Central Bank Working Paper, 1101, $1-43$.

Nogués, J. \& M. Grandes (2001), “Country Risk: Economic Policy, Contagions Effect or Political Noise?”, Journal of Applied Economics, IV(1), 125-162.

Organisation for Economic Cooperation and Development (OECD) (2014), OECD Economic Surveys: Turkey 2014, <http://www.oecd-ilibrary.org/economics/oecd-economicsurveys-turkey 2014_eco_surveys-tur-2014-en>, 02.06.2015.

Özatay, F. \& E. Özmen \& G. Şahinbeyoğlu (2009), "Emerging Market Sovereign Spreads, Global Financial Conditions and U.S. Macroeconomic News", Economic Modelling, 26(2), 526531.

Özatay, F. (2011), "The New Monetary Policy of the Central Bank: Two Targets-Three Intermediate Targets-Three Tools", Iktisat Işletme ve Finans, 26 (302), 27-43.

Özatay, F. (2014), “Turkey’s Distressing Dance with Capital Flows”, The Economic Policy Research Foundation of Turkey Report, R201407, 1-20.

Özdinçer, B. \& C. Özyıldırım (2010) "Türkiye Bankacılık Sektöründe Net Faiz Marjlarının

Belirlenmesinde Etkin Faktörler: Türkiye Analizi”, İktisat İşletme ve Finans, 25(292), 927.

Özmen, E. \& Ö.D. Yaşar, (2015), "Emerging Markets Sovereign Bond Spreads, Credit Ratings and Global Financial Crisis", ERC-Working Papers in Economics, 15/10, 1-29.

Peersman, G. (2002), "Monetary Policy and Long Term Interest Rates in Germany", Economic Letters, 77(2), 271-277.

Phillips, P. \& P. Perron (1988), “Testing for A Unit Root in Time Series Regression”, Biometrika, 75(2), 335-346.

Portilo, R. \& M.Y. Ustyugova (2015), “A Model for Monetary Policy Analysis in Uruguay”, IMF Working Paper, 15/170, 1-29.

Saunders, A. \& L. Schumacher (2000), "The Determinants of Bank Interest Rate Margins: An International Study", Journal of International Money and Finance, 19(2000), 813-832. 
Sen, A. (2003), "On Unit-Root Tests When the Alternative is a Trend Break Stationary Process", Journal of Business and Economics Statistics, 21, 174-184.

Shapiro, M. \& M. Watson (1988), "Sources of Business Cycles Fluctuations", in S. Fischer (ed.), NBER Macroeconomics Annual 1988, Vol. 3, MIT Press, 111-155.

Sims, C. (1980), "Macroeconomics and Reality”, Econometrica, 48(1), 1-48.

Sims, C. (1986), “Are Forecasting Models Usable for Policy Analysis?”, Federal Reserve Bank of Minneapolis Quarterly Review, 10(1), 2-16.

Stone, M. \& W.C. Walker \& Y. Yasui (2009), "From Lombard Street to Avenida Paulista: Foreign Exchange Liquidity Easing in Brazil in Response to the Global Shock of 2008-09", IMF Working Papers, 09/259, 1-35.

Swiston, A.J. (2011), "Official Dollarization as A Monetary Regime: Its Effects on El Salvador", IMF Working Papers, 11/129, 1-25.

Takáts, E. (2010), “Ageing and Asset Prices”, BIS Working Papers, 318, 1-25.

Tunay, K.B. \& A.M. Silpar (2006), "Türk Ticari Bankacılık Sektöründe Karlılı̆̆a Dayalı Performans Analizi-I”, Türkiye Bankalar Birliği, Araştırma Tebliğleri Serisi, 1.

Tunç C. \& A. Yavaş (2015), "Not All Credit is Created Equal: Mortgage vs Non-Mortgage Debt and Private Saving Rate in Turkey", CBRT Working Paper, 15/24. 1-24.

Türkiye Bankalar Birliği (TBB) (2015), Faaliyet Raporu 2014-2015, <https://www.tbb.org.tr/Content/Upload/Dokuman/6258/Faaliyet_Raporu_2014__2015.pdf>, 20.12.2015.

Türkiye Cumhuriyet Merkez Bankası (TCMB) (2005a), Enflasyon Hedeflemesi Rejiminin Genel Çerçevesi ve 2006 Yılında Para ve Kur Politikası, No. 2005-56, Ankara, <http://www.tcmb.gov.tr/wps/wcm/connect/b9659002-b4e9-4344-8ef8dab79aed7a24/DUY2005-56.pdf?MOD=AJPERES\&CACHEID=b9659002-b4e9-43448ef8-dab79aed7a24>, 18.04.2015.

Türkiye Cumhuriyet Merkez Bankası (TCMB) (2005b), Finansal İstikrar Raporu, Sayı:1, Ankara, <http://www.tcmb.gov.tr/wps/wcm/connect/d790dd5c-091e-474aaf86c2900c8cb67f/Fir_TamMetin.pdf?MOD=AJPERES\&CACHEID=ROOTWORKSP ACEd790dd5c-091e-474a-af86-c2900c8cb67f>, 10.12.2015.

Türkiye Cumhuriyet Merkez Bankası (TCMB) (2006), Finansal İstikrar Raporu, Sayı 2, Ankara, <http://www.tcmb.gov.tr/wps/wcm/connect/6569b7d9-8b86-4a659dbf868e2752e16b/Fir_TamMetin2.pdf?MOD=AJPERES\&CACHEID=ROOTWORKS PACE6569b7d9-8b86-4a65-9dbf-868e2752e16b>, 14.08.2009.

Türkiye Cumhuriyet Merkez Bankası (TCMB) (2011), Finansal İstikrar Raporu, Sayı 12, Ankara, <http://www.tcmb.gov.tr/yeni/evds/yayin/finist/Fir_TamMetin12.pdf>, 11.05.2015.

Türkiye Cumhuriyet Merkez Bankası (TCMB) (2012), Finansal İstikrar Raporu, Sayı 15, Ankara, <http://www.tcmb.gov.tr/wps/wcm/connect/9017ff6b-973b40ba843391430bdb7d6f/Fir_TamMetin15.pdf?MOD=AJPERES\&CACHEID=ROTWO RKSPACE9017ff6b-973b-40ba-8433-91430bdb7d6f>, 30.10.2013.

Türkiye Cumhuriyet Merkez Bankası (TCMB) (2014), Finansal İstikrar Raporu, Sayı 19, Ankara, $<$ http://www.tcmb.gov.tr/wps/wcm/connect/0ad4e6c3-b2c8-420993d25a4ee056a9e1/Fir_TamMetin19.pdf?MOD=AJPERES\&CACHEID=ROOTWORK SPACE0ad4e6c3-b2c8-4209-93d2-5a4ee056a9e1>, 10.01.2016.

Uribe, M. \& V.Z. Yue (2006), “Country Spreads and Emerging Countries: Who Drives Whom?”, Journal of International Economics, 69, 6-36. 
Varlık, S. (2017), “Ülke Risk Primi Şokunun Bankacılık Sisteminin Sağlamlığına Etkisi: SVAR Modeli Çerçevesinde Türkiye Örneği”, Sosyoekonomi, Vol. 25(33), 103-126.

Ünsal, D.F. (2011), "Capital Flows and Financial Stability: Monetary Policy and Macroprudential Responses", IMF Working Paper, 11/189, 1-28.

Wong, K.P. (1997), "On the Determinants of Bank Interest Margins under Credit and Interest Rate Risks", Journal of Banking \& Finance, 21(2), 251-271.

Zarruk, E.R. \& J. Madura (1992), "Optimal Bank Interest Margin under Capital Regulation and Deposit Insurance", Journal of Financial and Quantitative Analysis, 27(01), 143-149.

Zivot, E. \& D.W.K. Andrews (1992), "Further Evidence on the Great Crash, the Oil-Price Shock, and the Unit-Root Hypothesis", Journal of Business \& Economic Statistics, 10(3), 251270 .

\section{EK-1: Bankacılık Sağlamlık Endeksi}

Tablo: 1

BSI'nın Bileşenleri

\begin{tabular}{|c|c|c|c|}
\hline Faktörler & Değişkenler & $\begin{array}{c}\text { Endekse Etki } \\
\text { Yönü }\end{array}$ & Ağırlık \\
\hline \multirow{7}{*}{$\begin{array}{l}\text { SERMAYE YETERLİLİĞİ VE AKTİF } \\
\text { KALİTESİ }\end{array}$} & Kredi/Mevduat & + & 0.165 \\
\hline & \begin{tabular}{|l} 
Kredi/Toplam Aktif \\
\end{tabular} & + & 0.162 \\
\hline & Ana Sermaye/Risk Ağırlıklı Varlıklar & + & 0.156 \\
\hline & Mevduat/Toplam Aktif & + & 0.144 \\
\hline & Duran Aktif/Toplam Aktif & + & 0.142 \\
\hline & \begin{tabular}{|l|} 
Aktif/Özkaynak \\
\end{tabular} & + & 0.138 \\
\hline & \begin{tabular}{|l} 
Likit Aktif/Toplam Aktif \\
\end{tabular} & + & 0.093 \\
\hline \multirow{2}{*}{ KÂRLILIK } & Net Kâr/Özkaynak (ROE) & + & 0.500 \\
\hline & Net Kâr/Toplam Aktif (ROA) & + & 0.500 \\
\hline \multirow{2}{*}{ KREDİ RÍSKİ } & Net Takipteki Alacaklar/Toplam Krediler & - & 0.537 \\
\hline & Net Takipteki Alacaklar/Yasal Özkaynak & _- & 0.463 \\
\hline \multirow[t]{2}{*}{ PIYASA RISKİ } & $\begin{array}{l}\text { Üç Aya Kadar Faize Duyarlı Aktif/Üç Aya Kadar Faize Duyarlı } \\
\text { Pasif }\end{array}$ & + & 0.604 \\
\hline & Yabancı Para Net Genel Pozisyonu/Yasal Özkaynak & & 0.396 \\
\hline
\end{tabular}

Açıklamalar: (i) Değişkenlerin endekse etki yönü pozitif (+) olduğunda değiş̧kenlerdeki artış endeksi yükseltirken, değişsenlerin endekse etki yönü negatif (-) olduğunda değişkenlerdeki artış endeksi düsürmektedir. (ii) ROA: Return on Assets (Aktif Getiri Oranı). (iii) ROE: Return on Equity (Özkaynağa Göre Getiri). (iv) Yasal Özkaynak = (Ana Sermaye+ Katkı Sermaye) - Sermayeden İndirilen Değerler. (v) Yabancı Para Net Genel Pozisyonu=Bilânço İçi Yabancı Para Pozisyonu + Bilânço Dışı Kalemler. (vi) Piyasa Riski = Faiz Riski + Kur Riski.

\section{Grafik: 1}

\section{Bankacılık Sağlamlık Endeksi (BSI)}

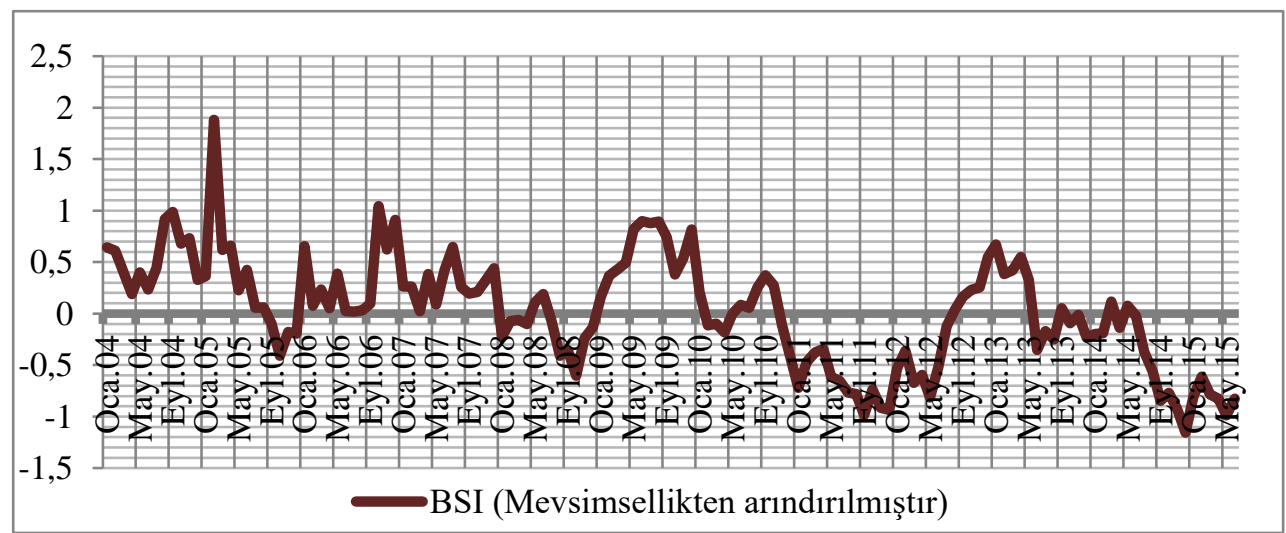

Kaynak: BDDK'dan elde edilen verilerden yararlanarak tarafimca oluşturulmuştur. 


\section{EK-2: Birim Kök Testi Bulguları}

Tablo: 2

ADF (1979) ve PP (1988) Birim Kök Testi Sonuçları

\begin{tabular}{|c|c|c|c|c|c|}
\hline \multirow[b]{2}{*}{ Değişkenler } & \multirow[b]{2}{*}{ Düzey/Fark } & \multicolumn{2}{|c|}{ ADF } & \multicolumn{2}{|c|}{ PP } \\
\hline & & Sabit Terim & $\begin{array}{c}\text { Trend ve } \\
\text { Sabit Terim }\end{array}$ & $\begin{array}{c}\text { Sabit } \\
\text { Terim }\end{array}$ & $\begin{array}{c}\text { Trend ve } \\
\text { Sabit Terim }\end{array}$ \\
\hline \multirow[t]{2}{*}{ EMBI+TR } & Düzey & $\begin{array}{l}-11.793 * \\
(0.0000)\end{array}$ & $\begin{array}{c}-11.751^{*} \\
(0.0000)\end{array}$ & $\begin{array}{l}-11.793 * \\
(0.0000)\end{array}$ & $\begin{array}{c}-11.751^{*} \\
(0.0000)\end{array}$ \\
\hline & Birinci Fark & --- & --- & --- & --- \\
\hline \multirow[t]{2}{*}{ REER } & Düzey & $\begin{array}{l}-9.326^{*} \\
(0.0000)\end{array}$ & $\begin{array}{l}-9.323^{*} \\
(0.0000)\end{array}$ & $\begin{array}{l}-8.934 * \\
(0.0000)\end{array}$ & $\begin{array}{l}-8.926^{*} \\
(0.0000)\end{array}$ \\
\hline & Birinci Fark & --- & --- & --- & -- \\
\hline \multirow[t]{2}{*}{ BISTFIN } & Düzey & $\begin{array}{l}-8.982^{*} \\
(0.0000)\end{array}$ & $\begin{array}{l}-8.999^{*} \\
(0.0000)\end{array}$ & $\begin{array}{l}-8.921 * \\
(0.0000)\end{array}$ & $\begin{array}{l}-8.934^{*} \\
(0.0000)\end{array}$ \\
\hline & Birinci Fark & -- & --- & -- & --- \\
\hline \multirow{2}{*}{ INTON } & Düzey & $\begin{array}{c}-2.550 \\
(0.1060)\end{array}$ & $\begin{array}{c}-1.195 \\
(0.9070)\end{array}$ & $\begin{array}{c}-2.509 \\
(0.1153)\end{array}$ & $\begin{array}{c}-1.195 \\
(0.9070)\end{array}$ \\
\hline & Birinci Fark & $\begin{array}{l}-10.010 * \\
(0.0000)\end{array}$ & $\begin{array}{c}-10.321^{*} \\
(0.0000)\end{array}$ & $\begin{array}{c}-10.020 * \\
(0.0000)\end{array}$ & $\begin{array}{c}-10.331 * \\
(0.0000)\end{array}$ \\
\hline \multirow[t]{2}{*}{ BSI } & Düzey & $-13.910^{*}(0.0000)$ & $\begin{array}{l}-13.860 * \\
(0.0000)\end{array}$ & $\begin{array}{l}-16.576^{*} \\
(0.0000)\end{array}$ & $\begin{array}{l}-16.532 * \\
(0.0000)\end{array}$ \\
\hline & Birinci Fark & --- & --- & --- & --- \\
\hline \multirow[t]{2}{*}{ SPREAD } & Düzey & $\begin{array}{l}-10.975^{*} \\
(0.0000)\end{array}$ & $\begin{array}{c}-10.936^{*} \\
(0.0000)\end{array}$ & $\begin{array}{l}-10.959 * \\
(0.0000)\end{array}$ & $\begin{array}{l}-10.918 * \\
(0.0006)\end{array}$ \\
\hline & Birinci Fark & --- & --- & --- & --- \\
\hline \multirow[t]{2}{*}{ OIL } & Düzey & $\begin{array}{l}-11.407 * \\
(0.0000)\end{array}$ & $\begin{array}{l}-11.588^{*} \\
(0.0000)\end{array}$ & $\begin{array}{l}-11.407 * \\
(0.0000)\end{array}$ & $\begin{array}{c}-11.589^{*} \\
(0.0000)\end{array}$ \\
\hline & Birinci Fark & --- & -- & --- & --- \\
\hline \multirow[t]{2}{*}{ VIX } & Düzey & $\begin{array}{l}-3.189 * * \\
(0.0228)\end{array}$ & $\begin{array}{c}-3.176 * * * \\
(0.0936)\end{array}$ & $\begin{array}{l}-3.038 * * \\
(0.0338)\end{array}$ & $\begin{array}{c}-3.024 * * * \\
(0.0962)\end{array}$ \\
\hline & Birinci Fark & --- & --- & --- & --- \\
\hline \multirow{2}{*}{ USTWO } & Düzey & $\begin{array}{c}-0.765 \\
(0.8252)\end{array}$ & $\begin{array}{c}-2.200 \\
(0.4853)\end{array}$ & $\begin{array}{c}-0.809 \\
(0.8130)\end{array}$ & $\begin{array}{c}-2.020 \\
(0.5849)\end{array}$ \\
\hline & Birinci Fark & $\begin{array}{l}-9.234^{*} \\
(0.0000)\end{array}$ & $\begin{array}{l}-9.244^{*} \\
(0.0000)\end{array}$ & $\begin{array}{l}-9.422 * \\
(0.0000)\end{array}$ & $\begin{array}{l}-9.425^{*} \\
(0.0000)\end{array}$ \\
\hline
\end{tabular}

Açılama: Birim kök testinde kullanılan gecikme saylsı Schwarz Bilgi Kriteri'ne (SIC) göre otomatik olarak belirlenmektedir. Çalışmada SIC'e göre belirlenen uygun gecikme uzunluğu 13 'tür. PP birim kök testinde NeweyWest bant geniş̧liği kullanılmaktadır. *işareti \%1, ** işareti \%5 ve *** işareti \%10 MacKinnon kritik değerlerinde serinin durağan olduğunu göstermektedir. Parantez içindeki değerler olasıllklart göstermektedir.

Tablo: 3

\section{ZA (1992) Birim Kök Testi Sonuçları}

\begin{tabular}{|c|c|c|c|c|c|c|c|}
\hline \multirow{2}{*}{ Değişkenler } & \multirow{2}{*}{ Düzey / Fark } & \multicolumn{3}{|c|}{ Model A } & \multicolumn{3}{|c|}{ Model C } \\
\hline & & Test İstatistiği & $\mathrm{k}$ & Kırılma Tarihi & Test İstatistiği & $\mathrm{k}$ & Kırılma Tarihi \\
\hline \multirow{2}{*}{ EMBI+TR } & Düzey & $-8.524 *$ & 2 & 2009:01 & $-8.694 *$ & 2 & 2008:11 \\
\hline & BirinciFark & --- & --- & --- & --- & --- & --- \\
\hline \multirow{2}{*}{ REER } & Düzey & $-6.783^{*}$ & 3 & 2011:09 & $-6.894 *$ & 3 & 2014:02 \\
\hline & BirinciFark & --- & --- & --- & --- & --- & --- \\
\hline \multirow{2}{*}{ BISTFIN } & Düzey & $-8.886^{*}$ & 2 & 2013:04 & $-8.854 *$ & 2 & 2010:09 \\
\hline & BirinciFark & --- & --- & --- & --- & --- & --- \\
\hline \multirow{2}{*}{ INTON } & Düzey & -3.689 & 1 & 2008:11 & -3.766 & 1 & 2008:11 \\
\hline & BirinciFark & $-10.836^{*}$ & 0 & 2008:10 & $-10.790^{*}$ & 0 & 2008:10 \\
\hline \multirow{2}{*}{ BSI } & Düzey & $-6.796^{*}$ & 2 & 2011:11 & 7.004* & 2 & 2012:07 \\
\hline & BirinciFark & --- & --- & --- & --- & --- & --- \\
\hline \multirow{2}{*}{ SPREAD } & Düzey & $-5.299 * *$ & 12 & 2006:06 & $-5.123^{* * *}$ & 12 & 2008:08 \\
\hline & BirinciFark & --- & --- & --- & --- & --- & --- \\
\hline \multirow{2}{*}{ OIL } & Düzey & $-5.846^{*}$ & 5 & 2009:03 & $-5.826^{*}$ & 5 & 2009:03 \\
\hline & BirinciFark & --- & --- & --- & --- & --- & --- \\
\hline \multirow{2}{*}{ VIX } & Düzey & $-5.561^{*}$ & 0 & 2007:05 & $-5.590^{*}$ & 0 & 2007:05 \\
\hline & BirinciFark & --- & --- & --- & --- & --- & --- \\
\hline \multirow{2}{*}{ USTWO } & Düzey & $-6.115^{*}$ & 5 & 2007:10 & -4.773 & 5 & 2007:06 \\
\hline & BirinciFark & $-7.040^{*}$ & 4 & 2006:06 & $-7.525^{*}$ & 4 & 2007:06 \\
\hline
\end{tabular}

Açıklama: $k$ gecikme sayısıdır. Model A için \%1, \%5 ve \%10 düzeyinde kritik değerler sırasılyla $-5.34,-4.80$ ve 4.58'dir. Model C için \%1, \%5 ve \%10 düzeyinde kritik değerler sirastyla $-5.57,-5.08$ ve -4.82 'dir. *işareti \%1, ** işareti $\% 5$ ve ***işareti $\% 10$ anlamlılık düzeylerini göstermektedir. 
Varlık, S. (2017), "Ülke Risk Primi Şokunun Bankacılık Sisteminin Sağlamlığına Etkisi: SVAR Modeli Çerçevesinde Türkiye Örneği”, Sosyoekonomi, Vol. 25(33), 103-126.

Tablo: 4

Lee-Strazicich (2003) İki Kırılmalı LM Birim Kök Testi Sonuçları

\begin{tabular}{|c|c|c|c|c|c|c|}
\hline \multirow[b]{2}{*}{ Değișkenler } & \multirow[b]{2}{*}{ Düzey /Fark } & \multicolumn{5}{|c|}{ Model C } \\
\hline & & Test İstatistiği & $\mathrm{k}$ & Kırılma Tarihi & Kırılma Tarihi Konumu & $\begin{array}{c}\text { Kritik } \\
\text { Değerler }\end{array}$ \\
\hline \multirow[t]{2}{*}{ EMBI+TR } & Düzey & $-12.150 *$ & 3 & $\begin{array}{l}2008: 08 \\
2008: 11\end{array}$ & $\lambda_{1}=0.401 \lambda_{2}=0.423$ & $\begin{array}{c}\% 1=-6.46 \\
\% 5=-5.67 \\
\% 10=-5.31\end{array}$ \\
\hline & Birinci Fark & --- & --- & --- & --- & --- \\
\hline \multirow[t]{2}{*}{ REER } & Düzey & $-7.964 *$ & 3 & $\begin{array}{l}2008: 07 \\
2011: 11\end{array}$ & $\begin{array}{l}\lambda_{1}=0.394 \\
\lambda_{2}=0.686\end{array}$ & $\begin{array}{c}\% 1=-6.42 \\
\% 5=-5.65 \\
\% 10=-5.32\end{array}$ \\
\hline & Birinci Fark & --- & --- & --- & --- & --- \\
\hline \multirow[t]{2}{*}{ BISTFIN } & Düzey & $-9.733^{*}$ & 0 & $\begin{array}{l}2008: 09 \\
2009: 05\end{array}$ & $\begin{array}{l}\lambda_{1}=0.409 \\
\lambda_{2}=0.467\end{array}$ & $\begin{array}{c}\% 1=-6.46 \\
\% 5=-5.67 \\
\% 10=-5.31\end{array}$ \\
\hline & Birinci Fark & --- & --- & --- & --- & --- \\
\hline \multirow{2}{*}{ INTON } & Düzey & -3.619 & 1 & $\begin{array}{l}2006: 05 \\
2009: 07\end{array}$ & $\begin{array}{l}\lambda_{1}=0.204 \\
\lambda_{2}=0.482\end{array}$ & $\begin{array}{c}\% 1=-6.40 \\
\% 5=-5.74 \\
\% 10=-5.32\end{array}$ \\
\hline & Birinci Fark & $-10.969 *$ & 2 & $\begin{array}{l}2008: 06 \\
2009: 03\end{array}$ & $\lambda_{1}=0.204 \lambda_{2}=0.234$ & $\begin{array}{c}\% 1=-6.16 \\
\% 5=-5.59 \\
\% 10=-5.28\end{array}$ \\
\hline \multirow[t]{2}{*}{ BSI } & Düzey & $-6.441^{*}$ & 0 & $\begin{array}{l}2011: 03 \\
2012: 06\end{array}$ & $\lambda_{1}=0.628 \lambda_{2}=0.803$ & $\begin{array}{c}\% 1=-6.32 \\
\% 5=-5.73 \\
\% 10=-5.32\end{array}$ \\
\hline & Birinci Fark & --- & --- & --- & --- & --- \\
\hline \multirow[t]{2}{*}{ SPREAD } & Düzey & $-5.445 * * *$ & 12 & $\begin{array}{l}2006: 07 \\
2012: 04\end{array}$ & $\lambda_{1}=0.219 \lambda_{2}=0.723$ & $\begin{array}{c}\% 1=-6.42 \\
\% 5=-5.65 \\
\% 10=-5.32\end{array}$ \\
\hline & Birinci Fark & --- & --- & --- & --- & --- \\
\hline \multirow[t]{2}{*}{ OIL } & Düzey & $-13.159 *$ & 5 & $\begin{array}{l}2008: 07 \\
2009: 06\end{array}$ & $\lambda_{1}=0.394 \lambda_{2}=0.474$ & $\begin{array}{c}\% 1=-6.46 \\
\% 5=-5.67 \\
\% 10=-5.31\end{array}$ \\
\hline & Birinci Fark & --- & --- & --- & --- & --- \\
\hline \multirow[t]{2}{*}{ VIX } & Düzey & $-6.749^{*}$ & 0 & $\begin{array}{l}2007: 01 \\
2009: 05\end{array}$ & $\lambda_{1}=0.263 \lambda_{2}=0.467$ & $\begin{array}{c}\% 1=-6.46 \\
\% 5=-5.67 \\
\% 10=-5.31\end{array}$ \\
\hline & Birinci Fark & --- & --- & --- & --- & --- \\
\hline \multirow{2}{*}{ USTWO } & Düzey & -4.681 & 5 & $\begin{array}{l}2007: 06 \\
2009: 11\end{array}$ & $\lambda_{1}=0.299 \lambda_{2}=0.511$ & $\begin{array}{c}\% 1=-6.46 \\
\% 5=-5.67 \\
\% 10=-5.31\end{array}$ \\
\hline & Birinci Fark & $-10.934 *$ & 13 & $\begin{array}{l}2007: 08 \\
2008: 05\end{array}$ & $\lambda_{1}=0.314 \lambda_{2}=0.380$ & $\begin{array}{c}\% 1=-6.46 \\
\% 5=-5.67 \\
\% 10=-5.31\end{array}$ \\
\hline
\end{tabular}

Açıklama: k gecikme sayısıdır. * işareti $\% 1$, ** işareti $\% 5$ ve *** işareti $\% 10$ anlamlılık düzeylerini göstermektedir. 


\section{EK-3: Etki-Tepki Analizi Bulguları}

Grafik: 2

Ülke Risk Priminde Meydana Gelen 1 S.D. Yapısal Şokun Etki-Tepki Fonksiyonları

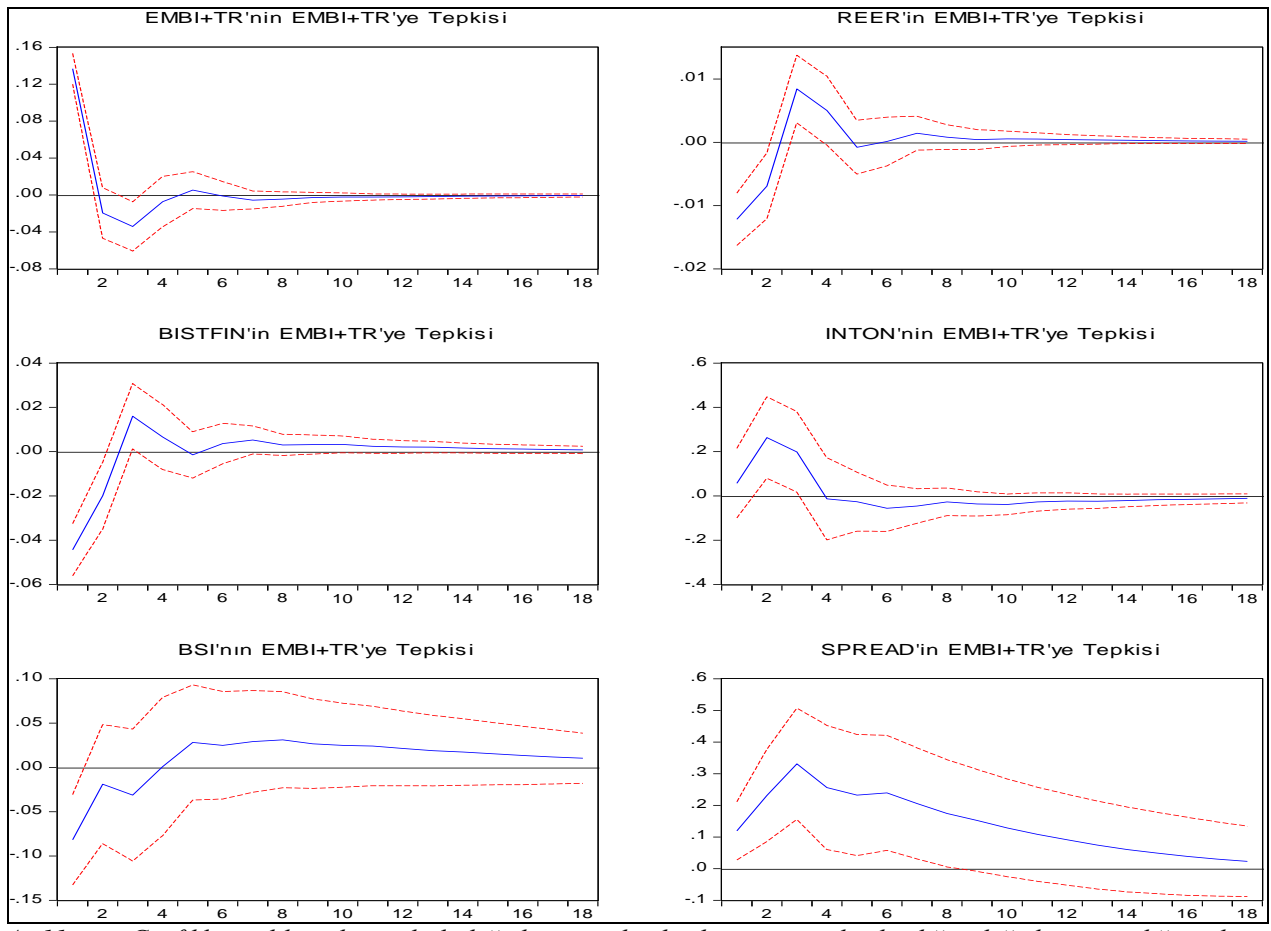

Açıklama: Grafiklerin dikey ekseni ilgili değişkene verilen bir birim yapısal şoka diğer değişkenin verdiği tepkinin yönünü ve büyüklügünü gösterirken, yatay eksen şokun verilmesinden sonra geçen 18 aylık süreyi göstermektedir. Düz çizgiler nokta tahminleri göstermekte, kesikli çizgiler ise değişkenlerin verdiği tepkiler için \pm 2 standart sapma güven aralıklarını temsil etmektedir.

\section{Tablo: 5}

BSI ve SPREAD'in Varyans Ayrıştırması (\%)

\begin{tabular}{|c|c|c|c|c|c|c|}
\hline \multicolumn{7}{|c|}{ BSI'NIN VARYANS AYRIŞTIRMASI } \\
\hline Dönem & $E M B I+T R$ & REER & BISTFIN & INTON & $B S I$ & SPREAD \\
\hline 6 & 3.9484 & 0.9362 & 5.2303 & 0.2778 & 84.4464 & 5.1606 \\
\hline 12 & 4.6195 & 3.5376 & 4.3084 & 0.3327 & 79.6550 & 7.5465 \\
\hline 18 & 4.9348 & 4.1184 & 4.2884 & 0.4059 & 78.1130 & 8.1392 \\
\hline 24 & 4.9975 & 4.1957 & 4.3040 & 0.4249 & 77.8622 & 8.2154 \\
\hline \multicolumn{7}{|c|}{ "SPREAD'IN VARYANS AYRIŞTIRMASI } \\
\hline Dönem & $E M B I+T R$ & REER & BISTFIN & INTON & BSI & SPREAD \\
\hline 6 & 20.6289 & 20.0858 & 3.2061 & 1.7942 & 2.1046 & 52.1801 \\
\hline 12 & 19.7739 & 19.0928 & 4.6213 & 2.5860 & 11.2305 & 42.6951 \\
\hline 18 & 18.3810 & 17.5109 & 4.6646 & 2.5526 & 18.0242 & 38.8664 \\
\hline 24 & 17.8392 & 16.9868 & 4.5861 & 2.4933 & 20.4009 & 37.6935 \\
\hline
\end{tabular}

